\title{
Using ALOS-2 Synthetic Aperture Radar (SAR) and Interferometric SAR to Detect Landslides on the Mountainous Island of Pohnpei, Federated States of Micronesia
}

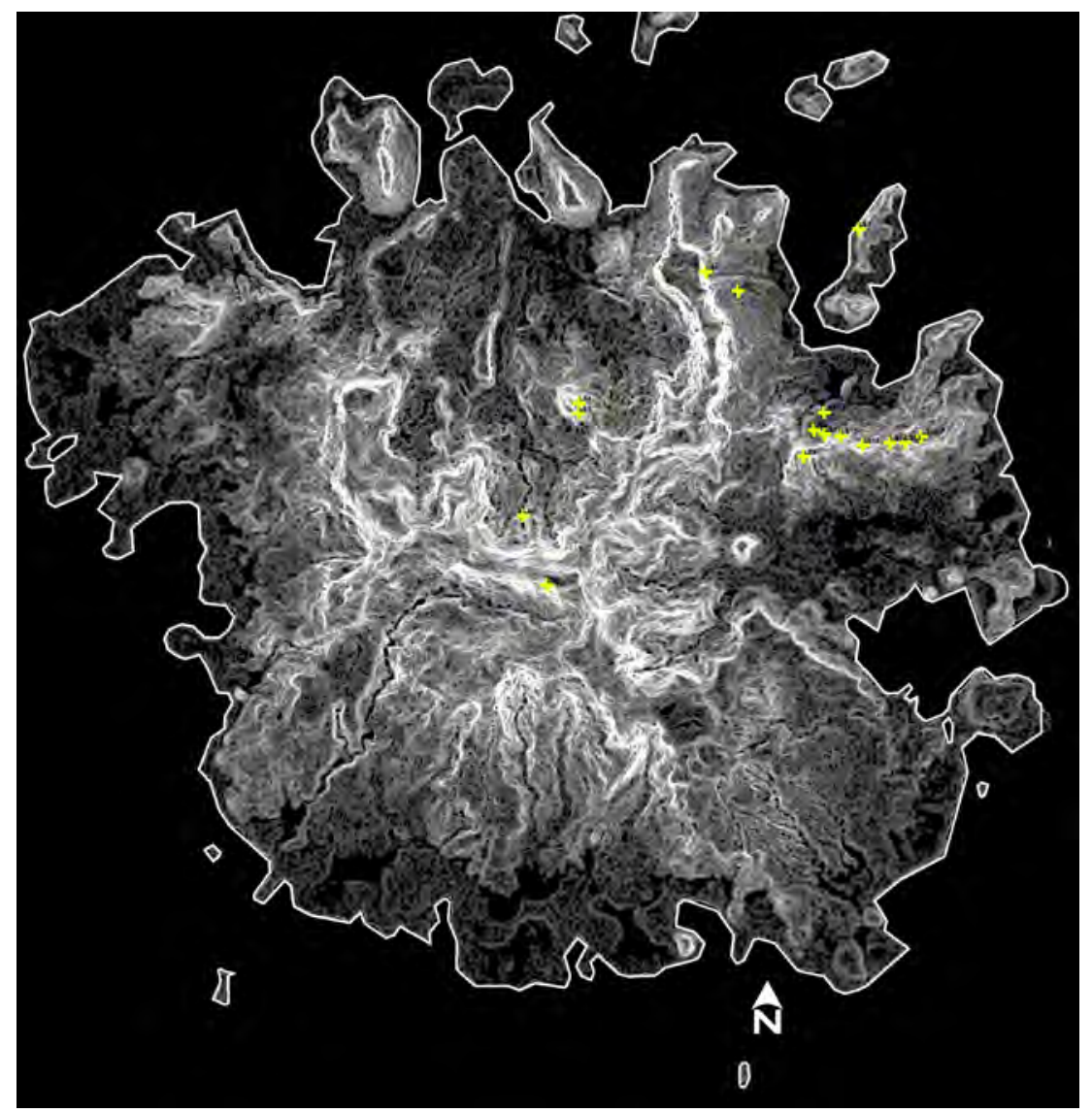

Open-File Report 2021-1084 
Cover. See figure $3 A$. 


\section{Using ALOS-2 Synthetic Aperture Radar (SAR) and Interferometric SAR to Detect Landslides on the Mountainous Island of Pohnpei, Federated States of Micronesia}

By Elijah W. Ramsey III and Amina Rangoonwala

Open-File Report 2021-1084 


\section{U.S. Geological Survey, Reston, Virginia: 2021}

For more information on the USGS - the Federal source for science about the Earth, its natural and living resources, natural hazards, and the environment—visit https://www.usgs.gov or call 1-888-ASK-USGS.

For an overview of USGS information products, including maps, imagery, and publications, visit https://store.usgs.gov/.

Any use of trade, firm, or product names is for descriptive purposes only and does not imply endorsement by the U.S. Government.

Although this information product, for the most part, is in the public domain, it also may contain copyrighted materials as noted in the text. Permission to reproduce copyrighted items must be secured from the copyright owner.

Suggested citation:

Ramsey, E.W., III, and Rangoonwala, A., 2021, Using ALOS-2 synthetic aperture radar (SAR) and interferometric SAR to detect landslides on the mountainous island of Pohnpei, Federated States of Micronesia: U.S. Geological Survey Open-File Report 2021-1084, 28 p., https://doi.org/10.3133/ofr20211084.

ISSN 2331-1258 (online) 


\section{Acknowledgments}

We recognize and thank Thomas Cecere of the U.S. Geological Survey (USGS) National Land Imaging Program, David Helweg of the USGS Northwest Pacific Islands Regional Office, Taire Eastmond of the U.S. Agency for International Development's Bureau for Humanitarian Assistance, and Snyther Biza and Skiis Dewey of the Department of Environment, Climate Change and Emergency Management of the Federated States of Micronesia National Government for their envisioned structure of risk research and applications that provided for this initial demonstration step within that structure. We thank Amy Koch of the Natural Resources Conservation Service for her assistance and support for the risk and applications research concept. We are grateful to Michael Poland of the USGS Yellowstone Volcano Observatory and Stephen Slaughter of the USGS National Landslide Hazards Program for their generous and invaluable contributions to the analysis methodologies and integrity of the processing used in this study. Stephen Slaughter provided the HazMapper land-cover change data for this project. We thank PCl Geomatics for their technical support, Sentinel Application Platform advisors for guidance and solutions, and the Japan Aerospace Exploration Agency for their support and patience.

The Advanced Land Observing Satellite (ALOS) and ALOS-2 data used in this study were provided to the USGS by the Japan Aerospace Exploration Agency and Japan Resources Observation System Organization under a Collaborative Research Agreement (nonfunded). 



\section{Contents}

Acknowledgments …............................................................................................................................

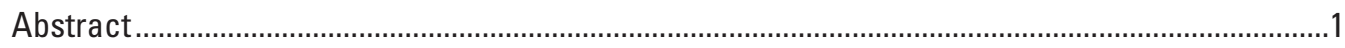

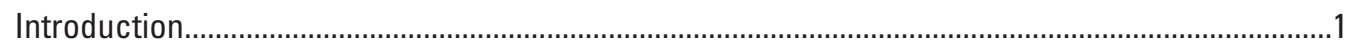

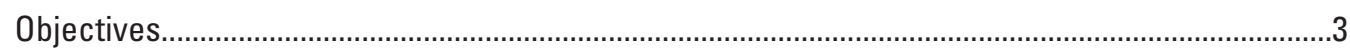

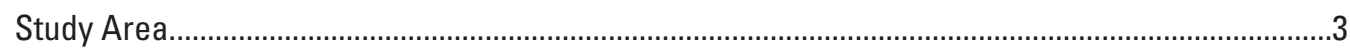

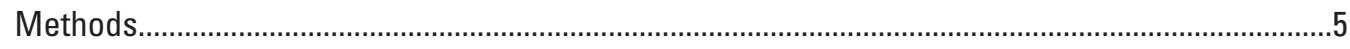

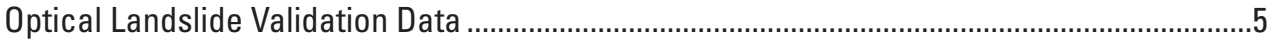

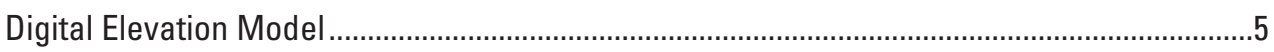

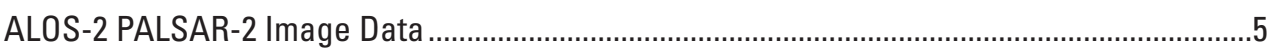

Intensity Processing for Change Detection ..........................................................................

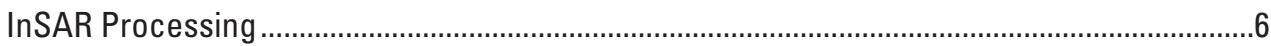

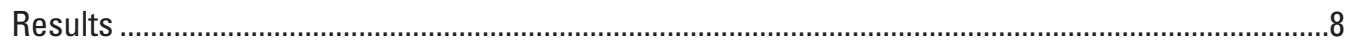

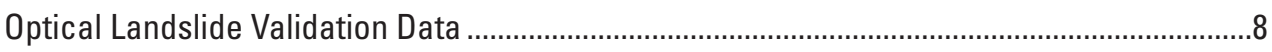

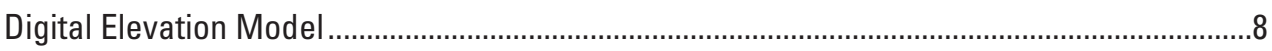

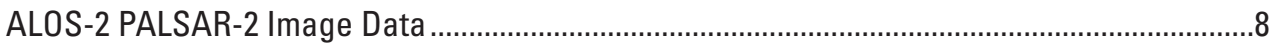

SAR Amplitude Processing for Change Detection ................................................................

InSAR Coherence Products ......................................................................................................

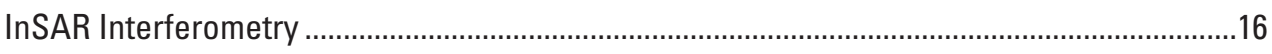

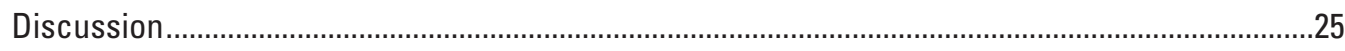

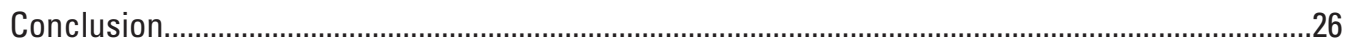

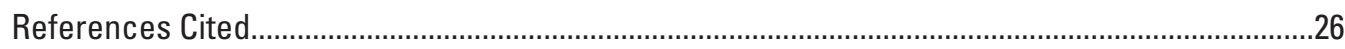

\section{Figures}

1. Map showing vegetation of Pohnpei, Federated States of Micronesia, 2002 ..................4

2. Map showing the ALOS-2 West and East orbit paths for image collections used to include the entire island of Pohnpei, Federated States of Micronesia.........................7

3. Maps showing slope based on 30-meter National Aeronautics and Space Administration Shuttle Radar Topography Mission data and 10-m digital elevation model map, Pohnpei, Federated States of Micronesia.

4. Maps showing full-coverage red-green-blue color composite of the East 2018 16 January, 27 March, and 3 July HV calibrated and ground-range images, Pohnpei, Federated States of Micronesia....

5. Map and images showing full-coverage red-green-blue color composite of the West 20187 January, 24 June, and 23 December HV calibrated ground-range and terrain-corrected images, Pohnpei, Federated States of Micronesia.

6. Map and images showing full-coverage West 20187 January to 24 June HV change log-ratio product, Pohnpei, Federated States of Micronesia.

7. Maps showing full-coverage 2019 East 1 January and 26 March and 2020 West 15 March and 21 June change ratio products, Pohnpei, Federated States of Micronesia

8. Maps showing the 2018 East 16 January and 27 March co-event and 2018 East 27 March and 3 July post-event coherence images, Pohnpei, Federated States of Micronesia 
9. Histograms reflecting the pre-co-event 2018 East 16 January and 27 March and post-co-event 2018 East 27 March and 3 July coherence distributions of the coherence images shown in figure 8

10. Map and images showing 2018 West 7 January and 24 June coherence full scene with crosses locating the 16 HazMapper land-cover change sites and Region 1 sites LS1, LS2, LS3, and LS4, Region 2 sites LS5, LS6, and LS7, and Region 3 sites LS8, LS9, LS10, LS11, LS12, LS13, LS14, LS15, and LS16, Pohnpei, Federated States of Micronesia

11. Map and images showing 2018 West 24 June and 23 December coherence full scene with crosses locating the 16 HazMapper land-cover change sites and Region 1 sites LS1, LS2, LS3, and LS4, Region 2 sites LS5, LS6, and LS7, and Region 3 sites LS8, LS9, LS10, LS11, LS12, LS13, LS14, LS15, and LS16, Pohnpei, Federated States of Micronesia

12. Map and images showing 2018 East 16 January and 27 March coherence full scene with crosses locating the 16 HazMapper land-cover change sites and Region 1 sites LS1, LS2, LS3, and LS4, Region 2 sites LS5, LS6, and LS7, and Region 3 sites LS8, LS9, LS10, LS11, LS12, LS13, LS14, LS15, and LS16, Pohnpei, Federated States of Micronesia

13. Map and images showing 2018 East 27 March and 3 July coherence full scene with crosses locating the 16 HazMapper land-cover change sites and Region 1 sites LS1, LS2, LS3, and LS4, Region 2 sites LS5, LS6, and LS7, and Region 3 sites LS8, LS9, LS10, LS11, LS12, LS13, LS14, LS15, and LS16, Pohnpei, Federated States of Micronesia..

\section{Tables}

1. Collection dates and near-scene incidence angles for 12 processed ALOS-2

Stripmode-3 images, Pohnpei, Federated States of Micronesia

2. Land-change locations, landslide details, and SAR amplitude and InSAR coherence landslide detection.

\section{Conversion Factors}

International System of Units to U.S. customary units

\begin{tabular}{|c|c|c|}
\hline Multiply & By & To obtain \\
\hline \multicolumn{3}{|c|}{ Length } \\
\hline meter $(\mathrm{m})$ & 3.281 & foot $(\mathrm{ft})$ \\
\hline kilometer (km) & 0.6214 & mile (mi) \\
\hline kilometer (km) & 0.5400 & mile, nautical (nmi) \\
\hline meter $(\mathrm{m})$ & 1.094 & yard (yd) \\
\hline \multicolumn{3}{|c|}{ Area } \\
\hline square kilometer $\left(\mathrm{km}^{2}\right)$ & 47.1 & acre \\
\hline
\end{tabular}




\section{Datum}

Horizontal coordinate information is referenced to the World Geodetic System of 1984 (WGS 84).

\section{Abbreviations}

$\begin{array}{ll}\text { ALOS } & \text { Advanced Land Observing Satellite } \\ \text { DEM } & \text { digital elevation model } \\ \text { GE } & \text { Google Earth } \\ \text { HH } & \text { horizontal send and horizontal return } \\ \text { HV } & \text { horizontal send and vertical return } \\ \text { InSAR } & \text { interferometric synthetic aperture radar } \\ \text { JAXA } & \text { Japan Aerospace Exploration Agency } \\ \text { PALSAR-2 } & \text { phased array type L-band SAR radar } \\ \text { RGB } & \text { red-green-blue } \\ \text { SAR } & \text { synthetic aperture radar } \\ \text { SNAP } & \text { Sentinel Application Platform software package } \\ \text { SLC } & \text { single look complex } \\ \text { SM3 } & \text { Stripmode } 3 \\ \text { USGS } & \text { U.S. Geological Survey } \\ \text { VH } & \text { vertical send and horizontal return } \\ \text { VV } & \text { vertical send and vertical return }\end{array}$





\title{
Using ALOS-2 Synthetic Aperture Radar (SAR) and Interferometric SAR to Detect Landslides on the Mountainous Island of Pohnpei, Federated States of Micronesia
}

\author{
By Elijah W. Ramsey III' and Amina Rangoonwala²
}

\begin{abstract}
This study was undertaken by the U.S. Geological Survey to assess the detectability of landslides in the densely forested and mountainous island of Pohnpei in the Federated States of Micronesia. The study used existing field-observed land-cover changes and landslides visible on Google Earth (GE) images. A limited number of ALOS-2 PALSAR-2 L-band synthetic aperture radar (SAR) images were collected on two adjacent orbit paths before and after an intense rainfall event that affected Pohnpei in mid-March 2018. Similar sets of images were collected in 2019 and 2020. Low coherence throughout the island interior eliminated use of phase-change products, and change analysis identified no landslide features as having formed in 2019 or 2020. The assessment of red-green-blue image composites and application of the log-ratio method to the 2018 ground-range SAR images identified 5 of the 11 landslides observed on the GE images. Visual comparisons of the co-event and post-event coherence image products detected 9 of the 11 landslides observed on the GE images. Combined, the ground-based SAR and interferometric SAR coherence change detections overcame high temporal and spatial decorrelations, identified all but one landslide visible in the GE comparison, and included substantial redundancy. The robustness of the landslide detection indicates that an increased collection frequency of L-band images could support systematic monitoring of land-cover change on Pohnpei at the scale reported in this study.
\end{abstract}

\footnotetext{
${ }^{1}$ U.S. Geological Survey.

${ }^{2}$ Cherokee Nation Technologies, under contract to the U.S. Geological Survey.
}

\section{Introduction}

A pilot study was undertaken to assess the technological ability to inventory landslide occurrences and impacts on the mountainous islands within the Federated States of Micronesia. As a worldwide occurrence, landslides, including debris flows, are stages of natural evolution in mountainous and hilly terrains (Raspini and others, 2017).

The rugged terrain and steep slopes of the Federated States of Micronesia mountainous islands, combined with tropical storms and typhoons, create an environment where landslide events are common and can cause widespread destruction and loss of life (Harp and others, 2004; Federated States of Micronesia, 2017). Landslides, however, may not be reported to government officials for weeks or not at all unless they interact with vulnerable elements (Mondini, 2017), especially those that impact rural areas. In addition, the distance between islands exacerbates the challenges for coordinated government response. Unreported landslides and insufficient details about the landslides may adversely impact community safety, health, and well-being. For instance, channel-scouring debris flows and catastrophic failure of landslide-dammed streams could pose immediate safety risks, as well as risks to subsistence farming and coastal fisheries by degradation of near-shore water quality. These landslide impacts can have long-term consequences to ecosystem resilience. Establishment of a systematic landslide inventory based on regular satellite imagery could help improve situational awareness in populated areas and government awareness in less populated areas.

Synthetic aperture radar (SAR) and optical image data are used frequently to detect landslides (for example, Del Ventisette and others, 2014; Tzouvaras and others, 2020). The advantage of using SAR data over optical image data is the ability to collect useable image data day and night unhindered by clouds and most weather conditions, particularly during emergency response events (Yun and others, 2015; Casagli and others, 2016; Burrows and others, 2020; Raucoules and others, 2020). In the mountainous islands of the Federated 
States of Micronesia, persistent cloud cover severely hinders the timeliness and consistency of useable optical collections. Unhindered SAR collections can decrease the latency between landslide occurrence and detection by satellite, and SAR can provide a consistent schedule for monitoring landslides once a repeatable detection method is established (Del Ventisette and others, 2014; Burrows and others, 2020; Raucoules and others, 2020; Ohki and others, 2020). Detection methods based on SAR use SAR amplitude or intensity, and interferometric SAR (InSAR) phase and coherence are used to capture the land-surface change from one or more pre-event images and similarly from one or more post-event images (for example, Burrows and others, 2020; Tzouvaras and others, 2020).

In the densely forested slopes of the Federated States of Micronesia mountainous islands, the dominant land-surface change expected by a landslide event is the removal of forest cover, which exposes bare soil throughout the landslide extent (Mondini, 2017). That dramatic change in the land cover alters the SAR signal interaction with the surface, and subsequently, the backscatter response to the sensor (Mondini, 2017; Ge and others, 2019; Ohki and others, 2020). In the densely forested slopes, even if the post-event SAR image collection occurs after some rapid vegetation regrowth, the SAR post-landslide backscatter will have changed in a manner dependent on the SAR system and the new growth structure (Ramsey and others, 2006, 2015). Satellite and sensor parameters most relevant to the detection of these land-cover changes are the wavelength, polarization, image collection frequency, and terrain characteristics (for example, Ge and others, 2019).

In the dense forest landscape, longer wavelength SAR generally provides deeper canopy penetration and interacts less with the canopy leaves and smaller stems and branches than shorter wavelength systems (Ramsey, 1998; Thirion and others, 2006). Full polarimetric systems provide a more complete perception of the canopy's biophysical structure than bipolarimetric systems (Ramsey and others, 2015). Within the same sensor system, like-polarizations (horizontal send and horizontal return $[\mathrm{HH}]$ or vertical send and vertical return [VV]) will interact less with the canopy and better emphasize the subcanopy direct or double-bounce scatter mechanism in comparison to cross-polarizations (horizontal send and vertical return $[\mathrm{HV}]$ or vertical send and horizontal return $[\mathrm{VH}]$ ) that are more influenced by increased roughness (for example, leaf volume, biomass) (Ramsey, 1998; Le Toan and others, 2004).

The juxtaposition of a sloping land gradient and landslides is a factor in SAR landslide mapping, and that factor is especially pertinent in the Federated States of Micronesia mountainous islands. For instance, landslides occurring on slopes facing the SAR look direction will present a higher scatter profile than landslides on slopes facing away from the look direction (Mondini, 2017; Ohki and others, 2020). The lower the scatter profile of the landslide feature, the less backscatter information is available to discern the landslide feature (Ohki and others, 2020). Based on the Ohki and others (2020) schematic, the incident geometry on higher slopes facing away from the sensor view can increase scatter away from the sensor. In that case, the full extent of the landslide may not be perceived by the SAR sensor, leading to a loss of landslide linear form on the image. Even facing the sensor, steep slopes associated with the mountainous terrain accentuate small changes in the SAR viewing geometry, promoting backscatter changes over multiple collections and affecting the SAR image quality (Mondini, 2017; Burrows and others, 2020; Ohki and others, 2020). In addition, the backscatter sensitivity to local incidence angle can accentuate changes in the scattering mechanism, resulting in varying mixtures of direct, double bounce, and volume scatter (Ohki and others, 2020) lowering coherence.

Generally, the techniques of SAR surface change capture rely on identifying changes in InSAR phase and coherence, calibrated SAR backscatter amplitude or intensity, or a combination of these changes that resulted from the landslide event. InSAR phase is unique in that its capability to monitor slowmoving surface deformation has proven useful in anticipating mass movements in mountainous regions (Del Ventisette and others, 2014; Casagli and others, 2016; Ge and others, 2019).

InSAR phase change between two or more dates can be used to determine the land movement associated with a landslide, thus providing a risk management tool (Raspini and others, 2017). The effective use of InSAR phase, however, relies on the send and the backscatter return maintaining a correlation or coherence value above 0.2 on a scale of zero (no coherence) to one (representing full coherence). Interaction of the radar with the vegetation canopy volume reduces coherence (Ramsey and others, 2006; Ohki and others, 2020), and wet leaf surfaces and leaf movement exacerbate that decorrelation (Ramsey and others, 2006; Tzouvaras and others, 2020). Increasing time between SAR image collections increases the potential of surface change resulting in temporal decorrelation and lowering coherence (Ramsey and others, 2006; Ohki and others, 2020). The use of longer wavelength sensors, likepolarizations ( $\mathrm{HH}$ or $\mathrm{VV}$ ), and shorter times between image acquisition reduces decorrelation, and thereby can improve phase interpretability.

The expectation was that the landslide would be indicated by a movement of the ground surface between the pre- and post-landslide images that may result in a phase difference between the two sets of images (Raspini and others, 2017; Ge and others, 2019; Tzouvaras and others, 2020). If the pre- and post-landslide backscatter coherence is high enough, the phase difference could be identified on the interferometric image product and interpreted as ground-surface movement. Lack of sufficient coherence would diminish appearance of a fringe pattern and eliminate interpretability and analysis of the phase product (Aimaiti and others, 2019). While phase products were created as part of this pilot landslide detection assessment, poor quality of the coherence prevented interpretable use of the produced interferograms for deformation. Because of that limitation, this study focuses on SAR amplitude and InSAR coherence change detection. 
InSAR coherence and SAR amplitude change detection methods are based on the landslide disruption of the surface to change the coherence or amplitude (Yun and others, 2015; Ge and others, 2019; Burrows and others, 2020). Whether the coherence or amplitude detection is based on single or multiple pre-event and post-event InSAR coherence or SAR amplitude pairs, the common expectation is that the post-event coherence or amplitude would be different from the pre-event coherence or amplitude (Natsuaki, 2018; Ge and others, 2019; Burrows and others, 2020; Ohki and others, 2020; Tzouvaras and others, 2020). While the generation of the InSAR coherence as a component of the InSAR phase generation would tend to be based on like-polarizations, SAR amplitude change production would preferentially use the cross-polarization to emphasize the pre-canopy backscatter (Le Toan and others, 2004; Mondini, 2017). Removal of the vegetation, particularly dense vegetation cover, by a landslide occurrence tends to decrease the backscatter amplitude (Mondini, 2017), especially that of the HV.

The landslide detection methods introduced in this pilot study only describe the simplest application of each method. These methods form the basis for the detection; however, these approaches are often more sophisticated and refined with coupled processing, such as slope and curvature from digital elevation model (DEMs) (Ohki and others, 2020), classification with known landslides (Ohki and others, 2020), variance instead of uniformity (Ohki and others, 2020), optical data integration (Casagli and others, 2016), and use of polarimetric SAR (Ohki and others, 2020).

\section{Objectives}

The study objectives were to assess the detectability of landslides in Pohnpei by using SAR satellite data and to evaluate operational methods that could provide a basis for systematic landslide occurrence monitoring within the Federated States of Micronesia (Burrows and others, 2020). The study period was centered on the intense rainfall event from Tropical Depression Jelawat that occurred on the island of Pohnpei during 16 and 17 March 2018. As part of the post-Jelawat damage assessment, field observations were conducted in Pohnpei in May 2018 by local and state government and organizations. That field damage assessment documented landslides that were believed to have resulted from the mid-March 2018 rainfall event (Federated States of Micronesia, 2019b).
This study was designed to use a limited number of existing ALOS-2 PALSAR-2 image collections of Pohnpei from before and after the rainfall event and to use the longer wavelength L-band to possibly decrease sensitivity to vegetation decorrelation (Natsuaki, 2018; Raucoules and others, 2020). Objectives were limited to the assessment of landslide detection and testing of operational methods that can lead to a consistent monitoring program. Consistent monitoring can inform emergency management and situational awareness for decision makers, helping them identify and increase their understanding of landslide hazards within the Federated States of Micronesia. The addition of post-2018 images and processing of those images support the 2018 analyses and further demonstrate the operational monitoring capability of the SARbased monitoring capabilities.

\section{Study Area}

The Federated States of Micronesia lie above the equator in the western Pacific Ocean about 2,500 miles southwest of Hawaii. Of the four states comprising the Federated States of Micronesia, Pohnpei state, lying in its eastern reaches, contains the largest island and highest peaks, and with a population around 36,000 , is the most populated and developed island (Federated States of Micronesia, 2019a). The island of Pohnpei accounts for 130 of the 133.4 square miles of the Pohnpei state land area. Pohnpei is a roughly circular shaped volcanic island that is 130 kilometers in circumference and has a rugged mountainous interior with peaks reaching 760 meters (m) (Federated States of Micronesia, 2019b). The island vegetation cover consists broadly of old growth rainforests, agroforests, and scattered secondary forests occupying the central mountainous region and mangrove swamps and marshes at the edges (fig. 1). The climate of Pohnpei is tropical and humid with rainfall strongly influenced by topography. Annual average rainfall ranges from $3.6 \mathrm{~m}$ on the coast to $8.3 \mathrm{~m}$ in the highland forest (Federated States of Micronesia, 2017). Although typhoons rarely impact Pohnpei (Federated States of Micronesia, 2019a), torrential rainstorms associated with tropical storms and depressions such as Tropical Depression Jelawat can precipitate landslides (Federated States of Micronesia, 2019b). 


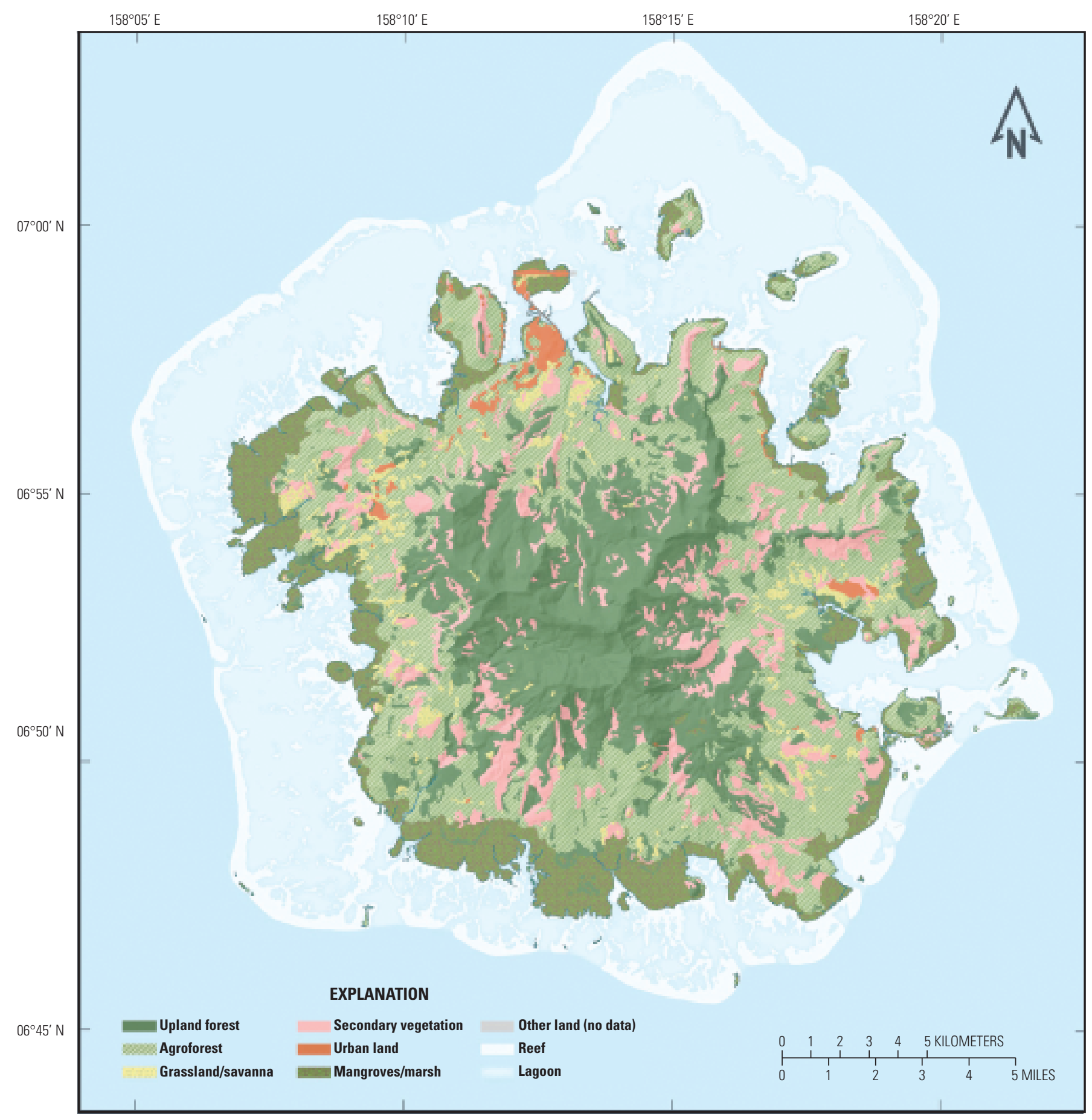

Source: The Nature Conservancy. Dataset was developed from color stereoscope interpretation of 1:15,000 aerial photographs obtained in May 2002.

Digital Atlas of Micronesia

Figure 1. Vegetation of Pohnpei, Federated States of Micronesia, 2002. Source: Digital Atlas of Micronesia, https://islandatlas.org/ pohnpei/vegetation/. 


\section{Methods}

\section{Optical Landslide Validation Data}

The study relied on the HazMapper tool for the mapping of land-cover change on Pohnpei (Scheip and Wegmann, 2021) and on observations from field reconnaissance of damages from landslides following an intense rainfall event in mid-March 2018 (Federated States of Micronesia, 2019b). Although the mapping and field reconnaissance observations of landslides occurred shortly after the rainfall event, the dates of occurrence for most landslides were not known and may not have been related to the rainfall event. Even so, the preponderance of rainfall-triggered landslides (for example, Ge and others, 2019) prompted us to use HazMapper, which had location data for landslides that were also visible on 2020 Google Earth (GE) imagery, and to use a limited number of available ALOS-2 PALSAR-2 L-band fine-resolution images from before and after the rainfall event. The combination of the HazMapper-located landslides, GE images, data from the 2018 rainfall event, and available PALSAR-2 L-band data provided a reasonable expectation for assessing the performance of the L-band SAR and InSAR change detection to indicate landslides in the mountainous landscape.

\section{Digital Elevation Model}

SAR and InSAR processing used the 10-m DEM of Pohnpei downloaded from the U.S. Geological Survey (USGS) website (https://apps.nationalmap.gov/downloader/ \#/elevation). The USGS DEM was reprojected to conform to the World Geodetic System 1984 (WGS 84) datum referenced in the latitude and longitude (Lat/Long) projection. In addition, calculation of the topographic slope relied on National Aeronautics and Space Administration Shuttle Radar Topography Mission global 30-m (SRTM_GL1) data distributed by OpenTopography and processing tools within the online Global Multi-Resolution Topography synthesis (Ryan and others, 2009).

\section{ALOS-2 PALSAR-2 Image Data}

As part of a nonfunded data agreement between the Japan Aerospace Exploration Agency (JAXA) and the USGS, ALOS-2 Stripmode 3 (SM3) fine-resolution, single-lookcomplex (SLC), level 1.1 SAR images of Pohnpei from 2018 to 2020 were downloaded from the JAXA website (table 1).

Table 1 contains the list of 12 processed ALOS-2 SM3 images including the collection dates, near-scene incidence angle, and orbit designation. Images used both for SAR and InSAR processing are denoted as master and slave. The image temporal baselines ranged from 67 to 351 days and averaged $142 \pm 86$ days. Perpendicular baselines ranged from -8.2 to $239.8 \mathrm{~m}$ and averaged $93 \pm 89 \mathrm{~m}$. The 2019 images were processed only for SAR amplitude change and perpendicular baselines are not reported for these image pairs.

Two orbital paths were needed to cover the entire island (fig. 2). Images of orbit 117 with a nominal near-scene incidence angle of $28.2^{\circ}$ were termed "East," and those of orbit 118 with a nominal near-scene incidence angle of $36.2^{\circ}$ were termed "West." The East and West images were collected on ascending orbits with a right look direction. The 2018 East

Table 1. Collection dates and near-scene incidence angles for 12 processed ALOS-2 Stripmode-3 images, Pohnpei, Federated States of Micronesia.

[Stack level, refers to M (master) and S (slave) and slave order noted numerically; Pair, refers to change calculation; Pbase, refers to perpendicular baseline; m, meter; Days, refers to days between pair collections; -, no interferometric synthetic aperture radar pair processed]

\begin{tabular}{cccccccr}
\hline Sensor name & $\begin{array}{c}\text { Orbit } \\
\text { number }\end{array}$ & $\begin{array}{c}\text { Collection date } \\
\text { (day-month-year) }\end{array}$ & $\begin{array}{c}\text { Near-scene } \\
\text { incidence } \\
\text { angle }\end{array}$ & Stack level & Pair & Pbase (m) & Days \\
\hline PALSAR-2 & 117 & 16-Jan-18 & 28.2 & $\mathrm{M}$ & $\mathrm{M}$ and S0 & 21 & 71 \\
PALSAR-2 & 117 & 27-Mar-18 & 28.2 & $\mathrm{~S} 0$ & M and S1 & 13.5 & 161 \\
PALSAR-2 & 117 & 3-Jul-18 & 28.2 & $\mathrm{~S} 1$ & S0 and S1 & -8.2 & 99 \\
PALSAR-2 & 117 & 1-Jan-19 & 28.2 & $\mathrm{M}$ & $\mathrm{M}$ and S0 & - & 67 \\
PALSAR-2 & 117 & 26-Mar-19 & 28.2 & $\mathrm{~S} 0$ & SO and S1 & - & 69 \\
PALSAR-2 & 117 & 2-Jul-19 & 28.2 & $\mathrm{~S} 1$ & $\mathrm{~S} 1$ and S2 & - & 147 \\
PALSAR-2 & 117 & 22-Oct-19 & 28.2 & $\mathrm{~S} 2$ & - & - & - \\
PALSAR-2 & 118 & 7-Jan-18 & 36.2 & $\mathrm{M}$ & $\mathrm{M}$ and S0 & 71.2 & 169 \\
PALSAR-2 & 118 & 24-Jun-18 & 36.2 & $\mathrm{~S} 0$ & $\mathrm{M}$ and S1 & 168 & 351 \\
PALSAR-2 & 118 & 23-Dec-18 & 36.2 & $\mathrm{~S} 1$ & $\mathrm{~S} 0$ and S1 & 239.8 & 183 \\
\hline PALSAR-2 & 118 & 15-Mar-20 & 36.2 & $\mathrm{M}$ & $\mathrm{M}$ and S0 & -129.7 & 99 \\
PALSAR-2 & 118 & 21-Jun-20 & 36.2 & $\mathrm{~S} 0$ & - & - & - \\
\hline
\end{tabular}


and West image sets were processed separately as were image sets collected in 2019 and 2020. The SLC azimuth and range pixel dimensions were about 2.7 by $6.5 \mathrm{~m}$, and the groundrange SAR pixel dimensions were equal after processing at $7 \mathrm{~m}$ or $10 \mathrm{~m}$.

\section{Intensity Processing for Change Detection}

Change detection was performed by calculating the logratio difference of the HV backscatter amplitude between two sets of images. In the three East and West 2018 images, the change analysis was only applied to the first image represented by the earliest 2018 pre-event image and the second sequential 2018 post-event image date. In both East and West image sets, those first and second images represented the co-event image pair.

The amplitude change detection was performed on the co-event image pairs by using the open-source Sentinel Application Platform (SNAP) software package of the European Space Agency (https://step.esa.int/main/toolboxes/ snap/). In 2018 East and West, the co-event amplitude pair incorporates the before- and first after-rainfall event SAR image collections.

To prepare the SLC image data for the amplitude detection procedure, the SLC data were calibrated to sigma naught, which is the backscatter per ground target area, taking into account the local incidence angle and range distance as well as noise and the sensor calibration. The calibrated image was converted from slant range to ground range. Next, the images per set (for example, all 2018 East images) were entered into the SNAP collocation tool where the secondary image or images were resampled to be geographically aligned with the primary image, which was the earliest date of the image set in all cases. The collocated images remained in the radar view geometry. Next, the collocated images were processed by the SNAP terrain correction tool which corrects geometric distortions resulting from side-looking (rather than nadir) imaging and the terrain. The terrain correction moved the image pixels into proper spatial relationship with each other while creating a geo-registered map product. Due to image blurring resulting from the terrain correction where there were steep slopes, both the collocated and terrain-corrected image sets were processed for change detection.

Two methods were used to detect backscatter magnitude change. Both methods relied nearly exclusively on HV polarization because of its higher sensitivity to removal of the vegetation canopy. Where two or more image dates composed the change detection suite, red-green-blue (RGB) composites of the collocated and terrain-corrected image sets provided a direct means for visual detection of landscape change (for example, Xue and others, 2018). For example, the pre- to post-landslide loss of vegetation cover should produce a post-slide decrease in HV backscatter that is predominantly shown in the RGB image as the color that was assigned in the pre-landslide image.

Although ratios for change detection vary (for example, Panuju and others, 2019), the second method of change detection calculated a simple logarithmic pre- and post-event $\mathrm{HV}$ ratio to determine the direction and magnitude of change (Mondini, 2017). The pre-event amplitude is placed in the numerator, and the post-event amplitude is placed in the denominator. A higher pre-event magnitude produces a positive log ratio, while the contrary produces a negative ratio. In these analyses, the calculated ratio and absolute change thresholds greater than or equal to abs $( \pm 0.1$ to \pm 0.2$)$ were commonly used to visualize change; however, in the change ratio application, limits were varied to enhance visual detection.

\section{InSAR Processing}

The ALOS-2 SLC data were processed to produce coherence and interferogram maps between two or more dates. The PCI Geomatica InSAR software package (2018) was used to process the primary and secondary SLC image data pairs (table 1). After coregistration, coherence and the raw interferogram maps for each pair were produced. The raw interferogram was then adjusted by removal of flat earth and topographic effects and residual orbital errors. The Goldstein filter for phase fringe enhancement followed by a multilook filter were applied to the interferogram to complete the processing for each pair. The final step involved unwrapping of the interferometric phase and interferometric adjustment of output products. All produced coherence and interferometric maps were aligned to the WGS 84 Lat/Long projection with the PCI Geomatica rational model by using image orbital and ancillary information.

Coherence change was based on a visual difference between two coherence pairs. In the SAR three-image sets for both 2018 East and West, the co-event coherence product (preevent and first post-event) was compared to the post-event coherence product (first post-event and second post-event). The strategy was set by the available images and differs from the more common use of single or multiple pairs of inclusively pre-event and post-event coherence products (Ge and others, 2019; Burrows and others, 2020). As in amplitude change detection, our 2018 co-event coherence pairs incorporate the before- and after-rainfall event SAR image collections. Using coherence change as a landslide detector was accomplished by visual comparison of the co-event and the post-event coherence pairs for both the East and West sets. 


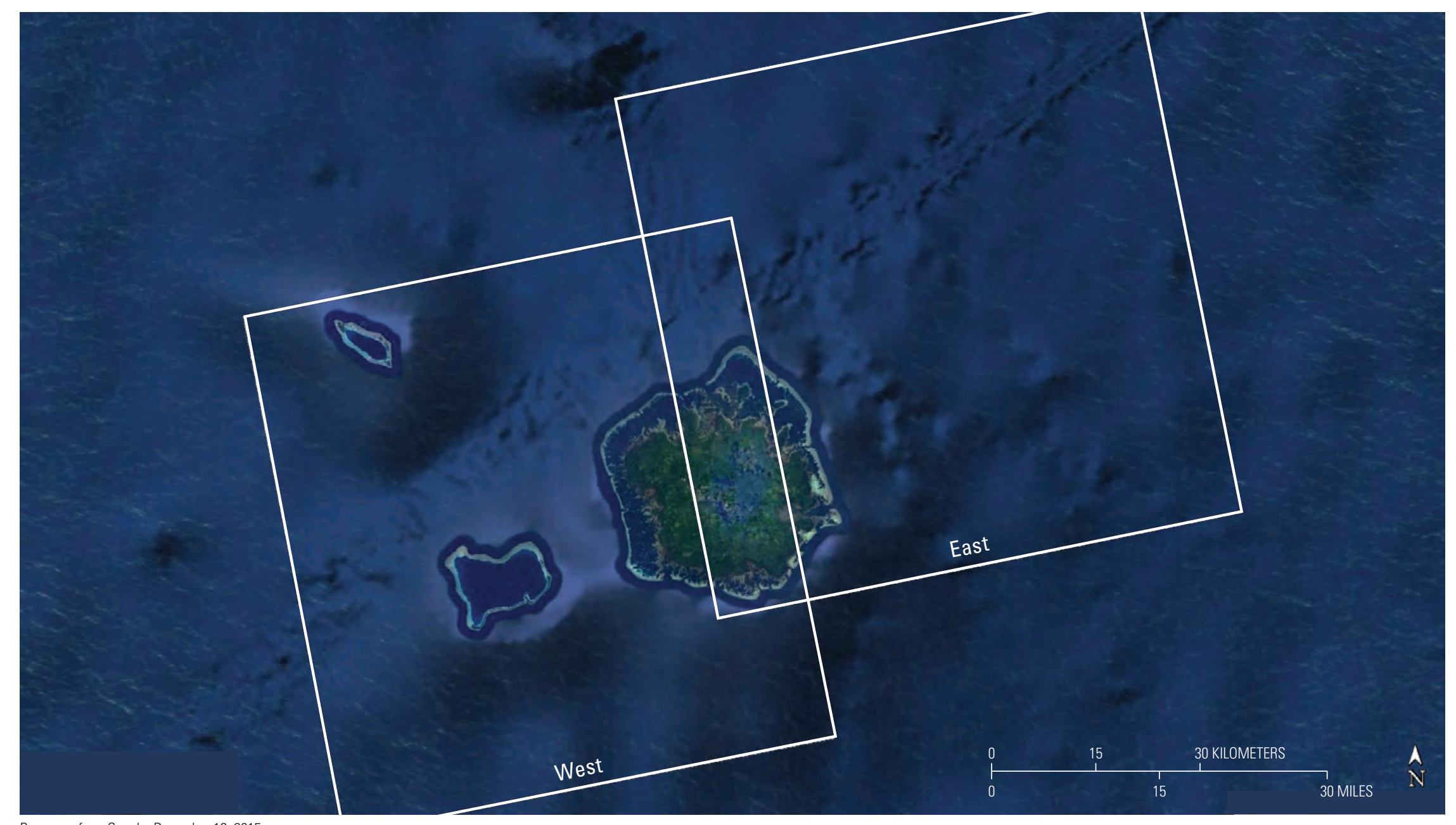

Base map from Google, December 13, 2015

Image from Landsat/Copernicus

Data from SIO, NOAA, U.S. Navy, NGA, and GEBCO

Figure 2. The ALOS-2 West and East orbit paths for image collections used to include the entire island of Pohnpei, Federated States of Micronesia. 


\section{Results}

\section{Optical Landslide Validation Data}

Of the 16 HazMapper-located change features identified as possible landslides, 5 locations did not exhibit change or change was indeterminant when the GE 2020 image was compared to the pre-rainfall event non-cloudy GE image (table 2). When comparing the 2015 and $2020 \mathrm{GE}$ images, the remaining 11 locations exhibited land-cover change, most often typical of the linear form of a landslide (table 2).

Of the nine landslides that exhibited a defined extent on the 2020 GE image, lengths and widths of landslide features were approximated from the GE image (table 2). The largest landslide was approximately $822 \mathrm{~m}$ long and $151 \mathrm{~m}$ wide. The lengths of the other landslides ranged from 70 to $397 \mathrm{~m}$ and averaged $209 \pm 103 \mathrm{~m}$; their widths ranged from 15 to $53 \mathrm{~m}$ and averaged $29 \pm 15 \mathrm{~m}$.

The SAR local incidence angles for each HazMapper coordinate were calculated by using the SNAP terrain correction tool. The SAR local incidence angles at each landslide coordinate location ranged from about 26 to $84^{\circ}$ and averaged $48 \pm 16^{\circ}$ in West orbits (table 2). Approximate local incidence angles for the East orbits ranged from 21 to $76^{\circ}$ and averaged $39 \pm 15^{\circ}$.

\section{Digital Elevation Model}

The 16 locations identified by the HazMapper optical analysis as possible landslides are depicted on the slope and DEM maps (figs. $3 A$ and $B$ ). Together, the depictions visually provide the physiographic nature of the 16 locations. Although most locations indicate the landslides initiated near the slope crest, four initiation points are located at lower elevations and slopes.

\section{ALOS-2 PALSAR-2 Image Data}

Each of the two offset and adjacent East and West ALOS-2 orbits needed to map the entire island collected three PALSAR-2 images during 2018 (table 1). While the times between all co-event and post-event pair collections were long, the 2018 West lapse time averaged $176 \pm 9$ days, two times the average of $85 \pm 20$ days between the 2018 East co-event and post-event collection pairs (table 1). In addition, in the 2018 East collections, LS5 was the only landslide with a projected SAR local incidence angle greater than $60^{\circ}$, and in the 2018 West collections, four landslides had local incidence angles greater than $60^{\circ}$ (table 2). L5 had the highest local incidence angle in the West and East collections. While increasing lapse time increases the likelihood of increased temporal decorrelation, higher local incidence angles, particularly associated with slopes facing away from the sensor (figs. $3 A$ and $B$ ), diminish the backscatter return to the satellite from the landslide location, decreasing detection likelihood. Further, the scattering mechanism varies highly with local incidence angle (Ohki and others, 2020), resulting in varying mixtures of direct, double bounce, and volume scatter, increasing the likelihood of poor coherence.

\section{SAR Amplitude Processing for Change Detection}

Two landslides were visible on the 2018 East and West RGB composite images. The East composite of 16 January, 27 March, and 3 July SAR amplitude captures the generation of the LS7 landslide feature (fig. 4). The post-landside loss of forest cover is masked in the steep slope high backscatter; however, the exposed landslide extension into the ocean creates a rough surface that acts to increase HV backscatter, thus providing an easily identifiable change feature. The increase in backscatter from 16 January to 27 March is unique; normally, backscatter would be decreased with the loss of vegetation cover caused by landslides. This increase in backscatter is similar to an increase in post-landslide amplitude caused by alluvium deposited at the foot of the landslide ( $\mathrm{Ge}$ and others, 2019). The West composite captures the LS1 landslide feature and illustrates a more expected change in HV backscatter following the removal of the forest cover (Mondini, 2017) (fig. 5). Other than these two landslide features, no additional landslide-induced changes were identified on the West or East RGB composites.

Applying the log-ratio tool to the 2018 East co-event SAR images to detect change only produced the slightly positive backscatter change related to the LS1 landslide and the negative backscatter change related to LS7. No additional features on the change product indicated variations due to landslide occurrence. Applying the log-ratio detection tool to the 2018 West co-event images highlighted four landslides: LS1, LS5, LS8, and LS11 (fig. 6). The 2018 SAR West images did not extend to cover the LS7 landslide extension into the ocean.

Applying the log-ratio change detection tool to the four 2019 East images showed no change features that would indicate landslides between the three image pairs composing the four image dates (fig. 7; table 1). Applying the log-ratio tool to the 2020 West 15 March and 21 June SAR image pair detected no positive change that would indicate a landslide feature.

\section{InSAR Coherence Products}

The produced 2018 East InSAR coherence images spanning 16 January to 27 March, before and just after the rainfall event, respectively, and 27 March to 3 July, after the event, showed low coherence throughout most of the island (figs. $8 \mathrm{~A}$ and $B$ ). Some high-coherence regions located in coastal areas include population centers and interior patches associated with clearings, buildup, possible flooding, and other non-landslide features. 
Table 2. Land-change locations, landslide details, and SAR amplitude and InSAR coherence landslide detection.

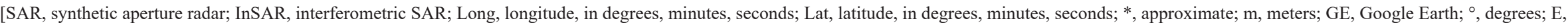

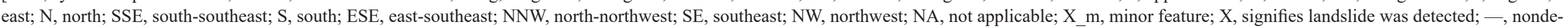

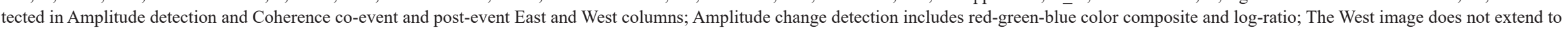
cover LS7 and LS16, and LS7 is not covered in East Coherence processing because it is restricted to pre-event land extent]

\begin{tabular}{|c|c|c|c|c|c|c|c|c|c|c|c|c|c|c|}
\hline \multirow{3}{*}{$\begin{array}{c}\text { Possible } \\
\text { landslide } \\
\text { feature } \\
\text { identified by } \\
\text { HazMapper }\end{array}$} & \multirow{2}{*}{\multicolumn{2}{|c|}{ Location }} & \multirow{3}{*}{$\begin{array}{c}\begin{array}{c}\text { West } \\
\text { image } \\
\text { set }\end{array} \\
\\
\begin{array}{c}\text { Local } \\
\text { incidence } \\
\text { angle }\end{array}\end{array}$} & \multirow{2}{*}{\multicolumn{3}{|c|}{ Landslide description ${ }^{1}$}} & \multirow{3}{*}{$\begin{array}{l}\text { GE image } \\
\text { comparison } \\
\text { (pre-event } \\
\text { to 2020) }\end{array}$} & \multirow{3}{*}{$\begin{array}{c}\text { East } \\
\text { image } \\
\text { set } \\
\\
\begin{array}{c}\text { Local } \\
\text { incidence } \\
\text { angle }^{2}\end{array}\end{array}$} & \multicolumn{2}{|c|}{$\begin{array}{l}\text { Amplitude change } \\
\text { detection from } \\
\text { image set }\end{array}$} & \multirow{2}{*}{$\begin{array}{c}\begin{array}{c}\text { Co- } \\
\text { event } \\
\text { coher- } \\
\text { ence }\end{array} \\
\begin{array}{c}\text { West } \\
2 \text { Jan - } \\
2 \text { Jun }\end{array} \\
\end{array}$} & \multirow{2}{*}{$\begin{array}{c}\text { Post-event } \\
\text { coherence } \\
\text { West } \\
24 \text { Jun - } \\
23 \text { Dec } \\
\end{array}$} & \multirow{2}{*}{ 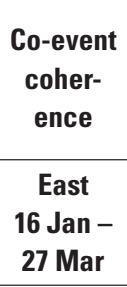 } & \multirow{2}{*}{$\begin{array}{c}\begin{array}{c}\text { Post- } \\
\text { event } \\
\text { coher- } \\
\text { ence }\end{array} \\
\begin{array}{r}\text { East } \\
27 \text { Mar- } \\
3 \text { Jul }\end{array} \\
\end{array}$} \\
\hline & & & & & & & & & $\begin{array}{c}2018 \\
\text { East }\end{array}$ & $\begin{array}{c}2018 \\
\text { West }\end{array}$ & & & & \\
\hline & Long & Lat & & $\begin{array}{l}\text { Length } \\
\text { (m) }\end{array}$ & $\begin{array}{c}\text { Width } \\
\text { (m) }\end{array}$ & Direction & & & yes & yes & yes & yes & yes & yes \\
\hline LS1 & $158^{\circ} 13^{\prime} 33.93^{\prime \prime} \mathrm{E}$ & $6^{\circ} 52^{\prime} 25.89^{\prime \prime} \mathrm{N}$ & $26^{\circ}$ & 822 & 151 & SSE & Landslide & $24^{\circ}$ & $\mathrm{X}$ & $\mathrm{X}$ & - & $X$ & - & $\mathrm{X}$ \\
\hline LS2 & $158^{\circ} 13^{\prime} 14.77^{\prime} \mathrm{E}$ & $6^{\circ} 53^{\prime} 21.10^{\prime} \mathrm{N}$ & $52^{\circ}$ & $\dagger$ & $\ddagger$ & $\ddagger$ & $\begin{array}{l}\text { No change } \\
\text { observed }\end{array}$ & $44^{\circ}$ & - & - & - & - & - & - \\
\hline LS3 & $158^{\circ} 13^{\prime} 58.65^{\prime \prime} \mathrm{E}$ & $6^{\circ} 54^{\prime} 42.09 ” \mathrm{~N}$ & $34^{\circ}$ & 397 & 53 & $\mathrm{~S}$ & Landslide & $26^{\circ}$ & - & - & - & $X$ & - & $\mathrm{X}$ \\
\hline LS4 & $158^{\circ} 13^{\prime} 58.83^{\prime \prime} \mathrm{E}$ & $6^{\circ} 54 ' 50.79 ’ \mathrm{~N}$ & $62^{\circ}$ & 65 & 24 & $\mathrm{E}$ & Landslide & $52^{\circ}$ & - & - & - & $\mathrm{X}$ & - & X_m \\
\hline LS5 & $158^{\circ} 15^{\prime} 39.38^{\prime \prime} \mathrm{E}$ & $6^{\circ} 56^{\prime} 34.96 ” \mathrm{~N}$ & $84^{\circ}$ & 181 & 22 & ESE & Landslide & $76^{\circ}$ & - & $\mathrm{X}$ & - & - & - & X_m \\
\hline LS6 & $158^{\circ} 16^{\prime} 4.99^{\prime \prime} \mathrm{E}$ & $6^{\circ} 56^{\prime} 20.16^{\prime \prime} \mathrm{N}$ & $68^{\circ}$ & $t$ & $t$ & $t$ & Undetermined & $55^{\circ}$ & - & - & - & - & - & - \\
\hline LS7 & $158^{\circ} 17^{\prime} 40.50^{\prime \prime} \mathrm{E}$ & $6^{\circ} 57^{\prime} 9.32 ” \mathrm{~N}$ & $32^{\circ}$ & $t$ & $t$ & NNW & Landslide & $23^{\circ}$ & $X$ & NA & - & - & - & - \\
\hline LS8 & $158^{\circ} 16^{\prime} 57.24^{\prime \prime} \mathrm{E}$ & 654'8.34”N & $56^{\circ}$ & 242 & 47 & SE & Landslide & $45^{\circ}$ & - & $\mathrm{X}$ & - & - & - & $\mathrm{X}$ \\
\hline LS9 & $158^{\circ} 17^{\prime} 5.45^{\prime \prime} \mathrm{E}$ & $6^{\circ} 54^{\prime} 29.47^{\prime \prime} \mathrm{N}$ & $36^{\circ}$ & $t$ & $t$ & $t$ & $\begin{array}{l}\text { No change } \\
\text { observed }\end{array}$ & $25^{\circ}$ & - & - & - & - & - & - \\
\hline LS10 & $158^{\circ} 17^{\prime} 13.48^{\prime \prime} \mathrm{E}$ & $6^{\circ} 54^{\prime} 43.27^{\prime \prime} \mathrm{N}$ & $46^{\circ}$ & $t$ & $\ddagger$ & $t$ & $\begin{array}{l}\text { No change } \\
\text { observed }\end{array}$ & $33^{\circ}$ & - & - & - & - & - & - \\
\hline LS11 & $158^{\circ} 17^{\prime} 13.79^{\prime \prime} \mathrm{E}$ & $6^{\circ} 54^{\prime} 26.10^{\prime} \mathrm{N}$ & $52^{\circ}$ & 247 & 17 & $\mathrm{~N}$ & Landslide & $41^{\circ}$ & - & X_m & - & $\mathrm{X}$ & - & $\mathrm{X}$ \\
\hline LS12 & $158^{\circ} 17^{\prime} 26.77^{\prime \prime} \mathrm{E}$ & $6^{\circ} 54^{\prime} 24.87^{\prime \prime} \mathrm{N}$ & $44^{\circ}$ & 141 & 20 & $\mathrm{~N}$ & Landslide & $32^{\circ}$ & - & - & - & $X$ & - & $X$ \\
\hline LS13 & $158^{\circ} 17^{\prime} 44.38^{\prime \prime} \mathrm{E}$ & $6^{\circ} 54^{\prime} 17.51 ” \mathrm{~N}$ & $62^{\circ}$ & $\ddagger$ & $\ddagger$ & $t$ & $\begin{array}{c}\text { Small change } \\
\text { observed }\end{array}$ & $50^{\circ}$ & - & - & - & - & - & $\mathrm{X}$ \\
\hline
\end{tabular}


Table 2. Land-change locations, landslide details, and SAR amplitude and InSAR coherence landslide detection. - Continued

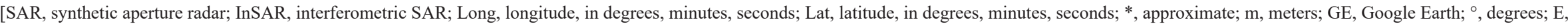

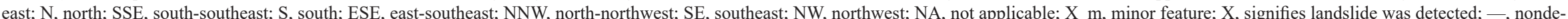

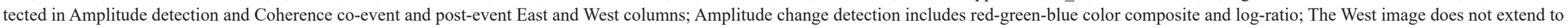
cover LS7 and LS16, and LS7 is not covered in East Coherence processing because it is restricted to pre-event land extent]

\begin{tabular}{|c|c|c|c|c|c|c|c|c|c|c|c|c|c|c|}
\hline \multirow{3}{*}{$\begin{array}{c}\text { Possible } \\
\text { landslide } \\
\text { feature } \\
\text { identified } \\
\text { by HazMap- } \\
\text { per }\end{array}$} & \multirow{2}{*}{\multicolumn{2}{|c|}{ Location }} & \multirow{2}{*}{$\begin{array}{c}\text { West } \\
\text { image } \\
\text { set }\end{array}$} & \multirow{2}{*}{\multicolumn{3}{|c|}{ Landslide description ${ }^{1}$}} & \multirow{3}{*}{$\begin{array}{l}\text { GE image } \\
\text { comparison } \\
\text { (pre-event } \\
\text { to 2020) }\end{array}$} & \multirow{3}{*}{$\begin{array}{c}\begin{array}{c}\text { East } \\
\text { image } \\
\text { set }\end{array} \\
\\
\begin{array}{c}\text { Local in- } \\
\text { cidence } \\
\text { angle }\end{array}\end{array}$} & \multicolumn{2}{|c|}{$\begin{array}{c}\text { Amplitude } \\
\text { change detection } \\
\text { from image set }\end{array}$} & \multirow{2}{*}{$\begin{array}{c}\begin{array}{c}\text { Co- } \\
\text { event } \\
\text { coher- } \\
\text { ence }\end{array} \\
\text { West } \\
2 \text { Jan - } \\
2 \text { Jun } \\
\end{array}$} & \multirow{2}{*}{$\begin{array}{c}\begin{array}{c}\text { Post- } \\
\text { event } \\
\text { coher- } \\
\text { ence }\end{array} \\
\begin{array}{c}\text { West } \\
24 \text { Jun - } \\
23 \text { Dec }\end{array}\end{array}$} & \multirow{2}{*}{$\begin{array}{c}\begin{array}{c}\text { Co-event } \\
\text { coher- } \\
\text { ence }\end{array} \\
\begin{array}{c}\text { East } \\
16 \text { Jan - } \\
27 \text { Mar }\end{array}\end{array}$} & \multirow{2}{*}{$\begin{array}{c}\begin{array}{c}\text { Post- } \\
\text { event } \\
\text { coher- } \\
\text { ence }\end{array} \\
\begin{array}{c}\text { East } \\
27 \text { Mar - } \\
3 \text { Jul }\end{array}\end{array}$} \\
\hline & & & & & & & & & $\begin{array}{l}2018 \\
\text { East }\end{array}$ & $\begin{array}{l}2018 \\
\text { West }\end{array}$ & & & & \\
\hline & Long & Lat & $\begin{array}{l}\text { Local in- } \\
\text { cidence } \\
\text { angle }^{2}\end{array}$ & $\begin{array}{l}\text { Length } \\
\text { (m) }\end{array}$ & $\begin{array}{l}\text { Width } \\
\text { (m) }\end{array}$ & Direction & & & yes & yes & yes & yes & yes & yes \\
\hline LS14 & $158^{\circ} 18^{\prime} 5.70^{\prime \prime} \mathrm{E}$ & $6^{\circ} 54^{\prime} 19.04 ” \mathrm{~N}$ & $30^{\circ}$ & 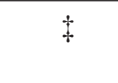 & $\$$ & 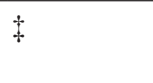 & $\begin{array}{l}\text { No change } \\
\text { observed }\end{array}$ & $21^{\circ}$ & - & - & - & - & - & - \\
\hline LS15 & $158^{\circ} 18^{\prime} 17.75^{\prime \prime} \mathrm{E}$ & $6^{\circ} 54^{\prime} 19.66^{\prime \prime} \mathrm{N}$ & $36^{\circ}$ & 70 & 15 & NW & Landslide & $27^{\circ}$ & - & - & - & - & - & - \\
\hline LS16 & $158^{\circ} 18^{\prime} 30.56^{\prime \prime} \mathrm{E}$ & $6^{\circ} 54 ' 24.29{ }^{\prime \prime} \mathrm{N}$ & NA & 182 & 29 & NW & Landslide & $33^{\circ}$ & - & - & - & - & - & $X$ \\
\hline
\end{tabular}

${ }_{1 \ddagger}^{\ddagger}$, landslide extent was difficult to discern, or no change was apparent on GE images. Length and Width estimated with Google Earth.

${ }^{2}$ Local incidence angle was estimated at the HazMapper coordinate. 

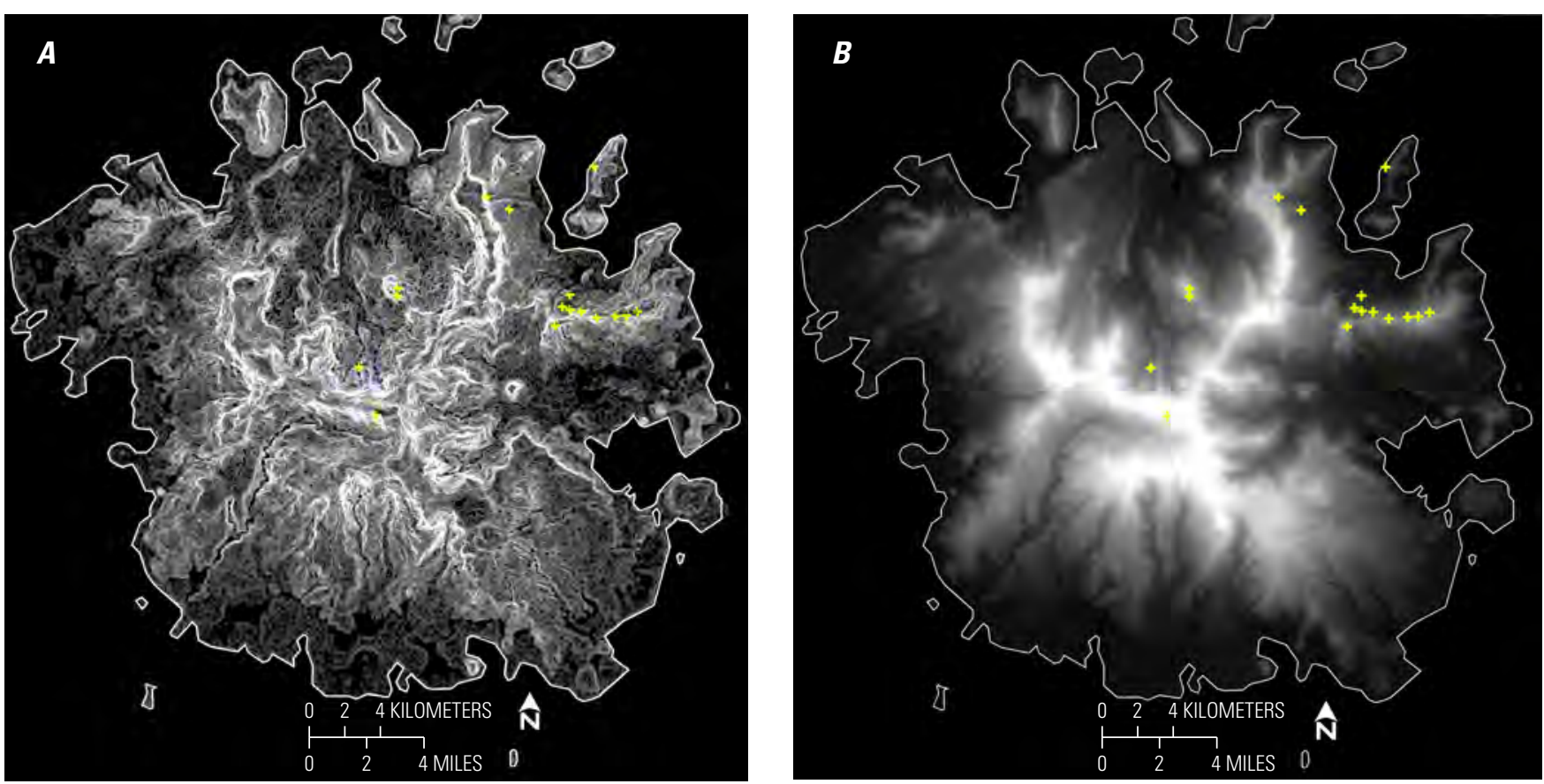

Figure 3. (A) Slope based on 30-meter $(\mathrm{m})$ National Aeronautics and Space Administration Shuttle Radar Topography Mission data and $(B)$ 10-m digital elevation model (DEM) map, Pohnpei, Federated States of Micronesia. The 16 possible landslide locations are overlain on the slope and DEM maps. On both maps, the gray to white transition signifies low to high values.

The histogram representations of these coherence maps with means and standard deviations of the co-event $(0.182 \pm 0.106)$ and post-event $(0.181 \pm 0.107)$ confirm the overall low coherence and the minor proportion of the island exhibiting a coherence greater than or equal to 0.2 (fig. 9). It is within that high similarity reflected in the histograms that relatively small, localized features exhibiting a co-event to post-event change from low to high coherence are identified as land-cover change possibly induced by a landslide. Further, the encompassing low coherence throughout the dominantly forested island interior indicates little confidence that produced phase maps would provide interpretable information for landslide detection.

Although phase change is not likely to be useful for landslide detection in this landscape, the possibility of coherence detection remains. The low-coherence dominance of the interior, apparent in both the co-event and the post-event image change composites, offers a test of the hypothesis that a landslide will result in increased coherence. In low-coherencedominated terrain, the co-event period should exhibit a low coherence in contrast to the higher coherence of the post-event period following the landslide occurrence and removal of vegetation. Given the minimal image collection points before and after the rainfall event, automated analysis of pre-event and post-event coherence image averages is not applicable for this assessment. Instead, visual inspection of the coherence change associated with the landslide locations meets the objectives of this pilot assessment study.
The pattern for assessment of coherence detection of landslides is exhibited in figure 10. The co-event coherence image product is displayed in a shaded relief rendition offered in PCI Geomatica. That rendition enhances the contrast between the low coherence dominating the island and higher coherence in some locations and regions. The 16 locations where landslides possibly occurred were separated into three regions (fig. 10A) to improve visual determination of the presence or absence of a coherence change feature and the shape of the feature. Only the 16 possible landslide locations are discussed with respect to the occurrence of change features.

Inspection of the co-event 2018 West 7 January and 24 June coherence period shows only a small coherence feature at LS12 (fig. 10D). Other than that small feature, no coherence change features are apparent at any of the 16 locations. On the 2018 West 24 June to 23 December post-event coherence image, however, change features are apparent at LS1, LS3, LS4, LS11, and LS12 (figs. $11 B$ and D). The LS12 feature is fully formed on this image (fig. 11D), while the LS11 feature is more subtle. A minor feature is located at LS2 (fig. 11B).

As in the West, the co-event 2018 East 16 January and 27 March coherence period shows only a small coherence feature at LS1 (fig. 12B). Like LS12 in the West image, the co-event East LS1 feature is very minor in comparison to the East LS1 post-event feature and looks to be an artifact of the steep slope. Like the West post-event period, the post-event 2018 East 27 March and 3 July period exhibits coherence features associated with landslides (fig. 13). Coherence landslide features are visible at LS1, LS3, LS4, LS5, LS8, LS11, 

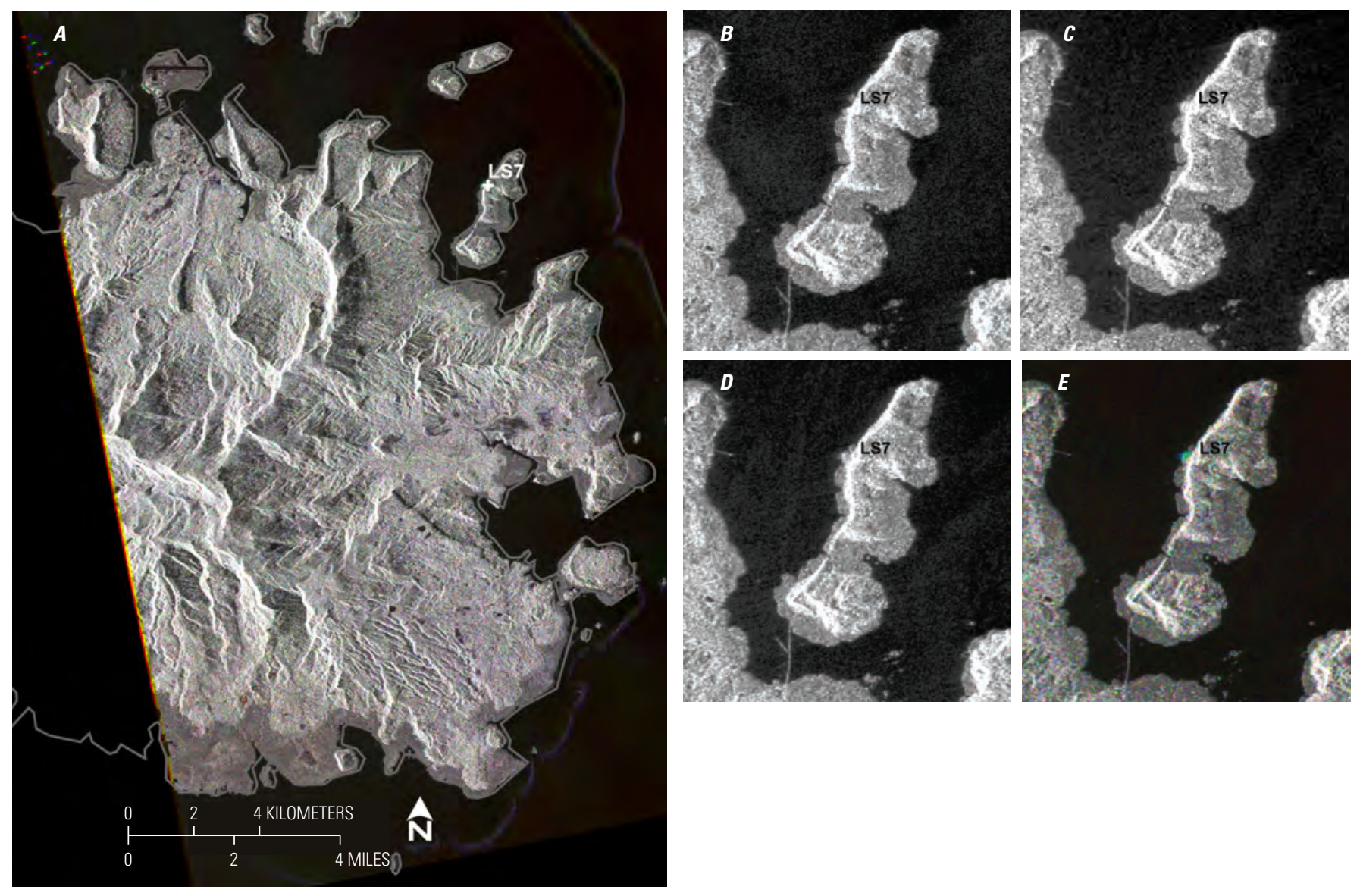

Figure 4. (A) Full-coverage red-green-blue (RGB) color composite of the East 201816 January, 27 March, and 3 July HV calibrated and ground-range images, Pohnpei, Federated States of Micronesia. Subsets show the transition from $(B) 16$ January pre-landslide to landslide LS7 occurrence and extension into the coastal ocean, $(C) 27$ March, and $(D) 3$ July, and $(E)$ the RGB color composite exhibiting the ocean low backscatter amplitude of 16 January, and the 27 March and 3 July higher backscatter post-landslide dominated by the nearly white hue on the 27 March image. 

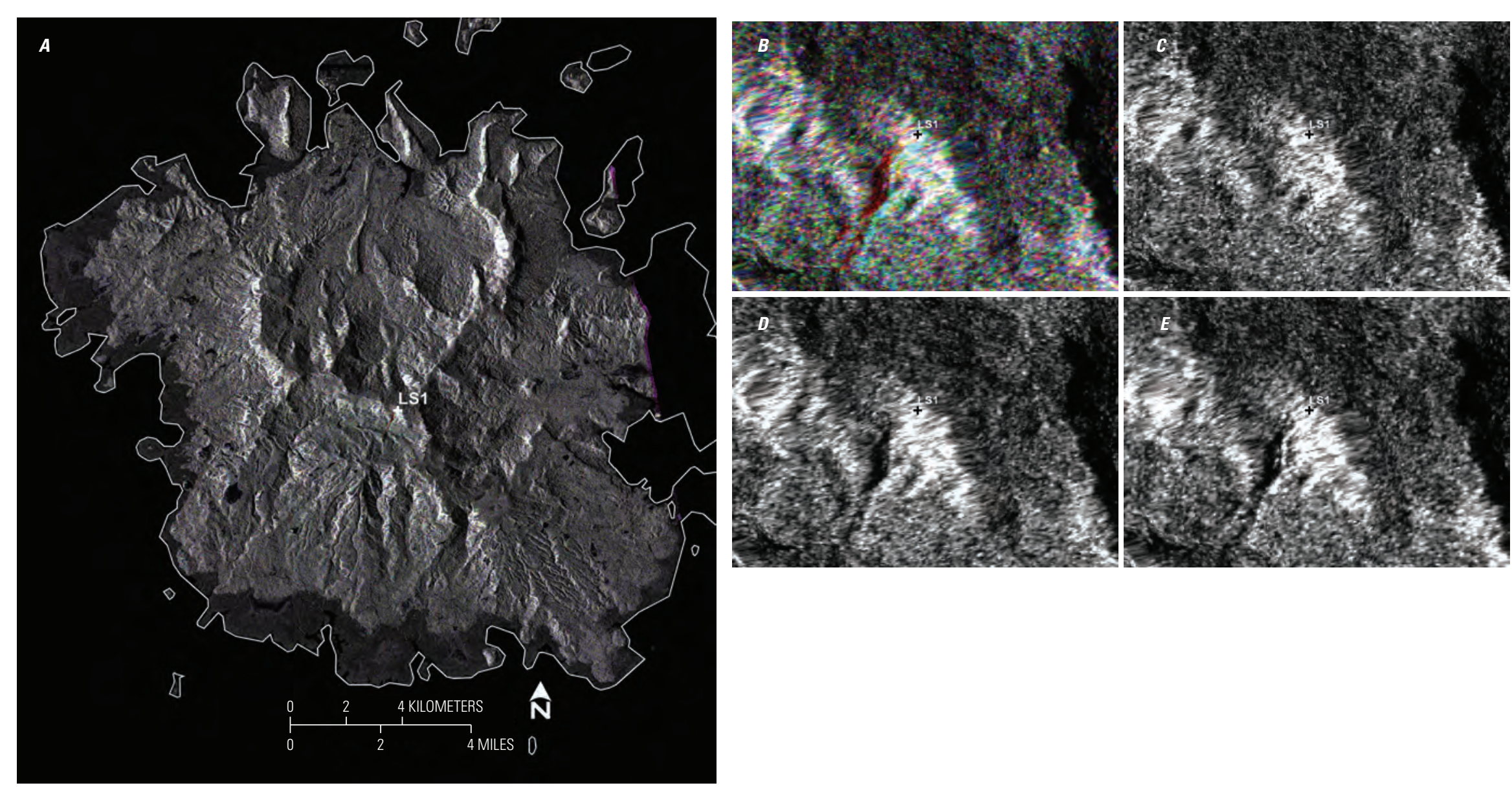

Figure 5. (A) Full-coverage red-green-blue (RGB) color composite of the West 20187 January, 24 June, and 23 December HV calibrated ground-range and terrain-corrected images, Pohnpei, Federated States of Micronesia. Subsets centered on LS1 show the transition from (B) the same West 20187 January, 24 June, and 23 December HV RGB color composite and $(C) 7$ January forest high backscatter to the low backscatter depicted on $(D) 24$ June and $(E) 23$ December after removal of the forest canopy. The three-date RGB color composite depicts the dramatic loss of forest canopy by emphasizing the pre-landslide backscatter assigned the red color. 

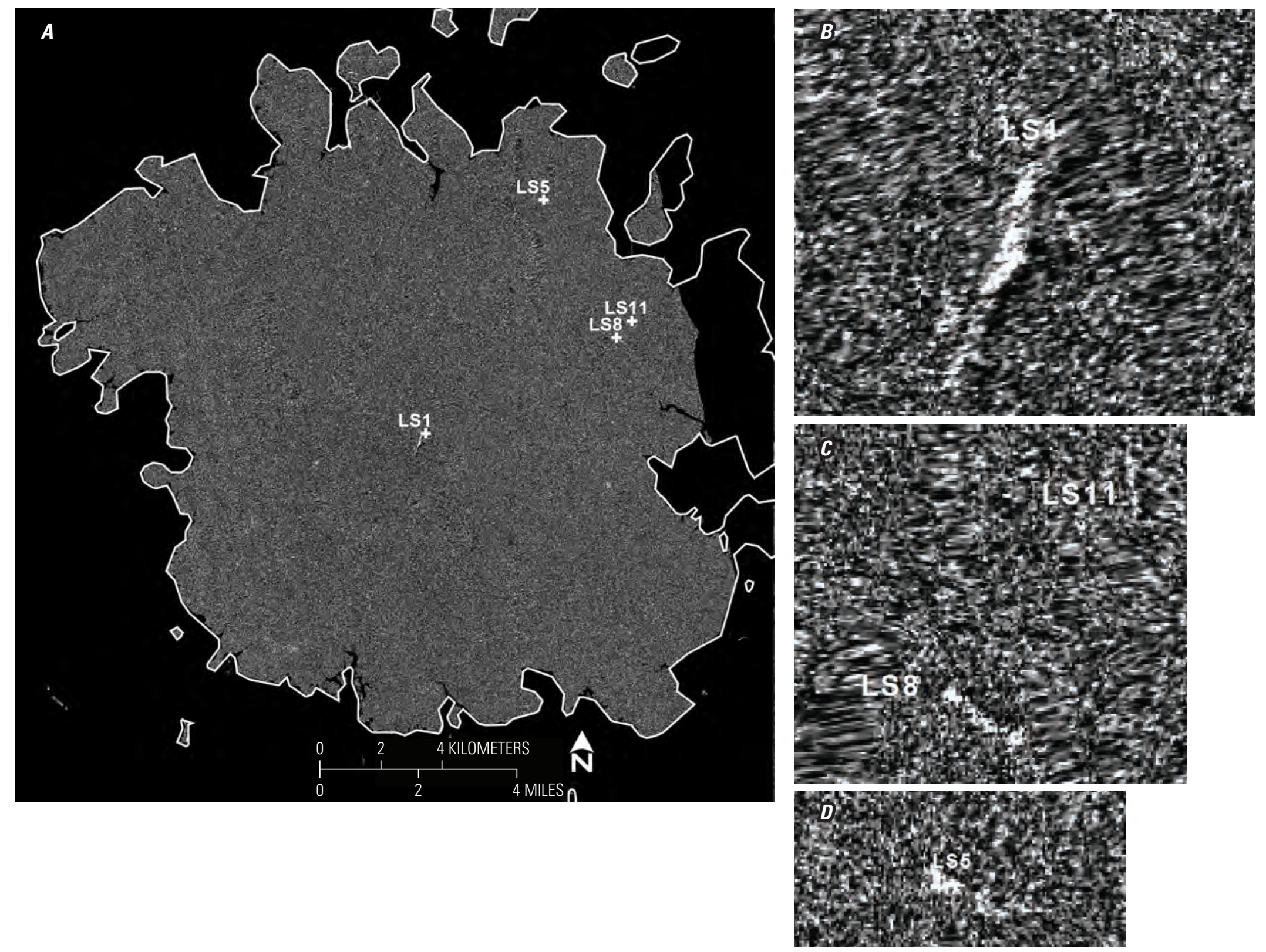

Figure 6. (A) Full-coverage West 20187 January to 24 June HV change log-ratio product, Pohnpei, Federated States of Micronesia. The subsets (B) LS1, (C) LS8 and LS11, and (D) LS5 illustrate the unique forms of the features used to identify the landslides in the highly variable change background. 

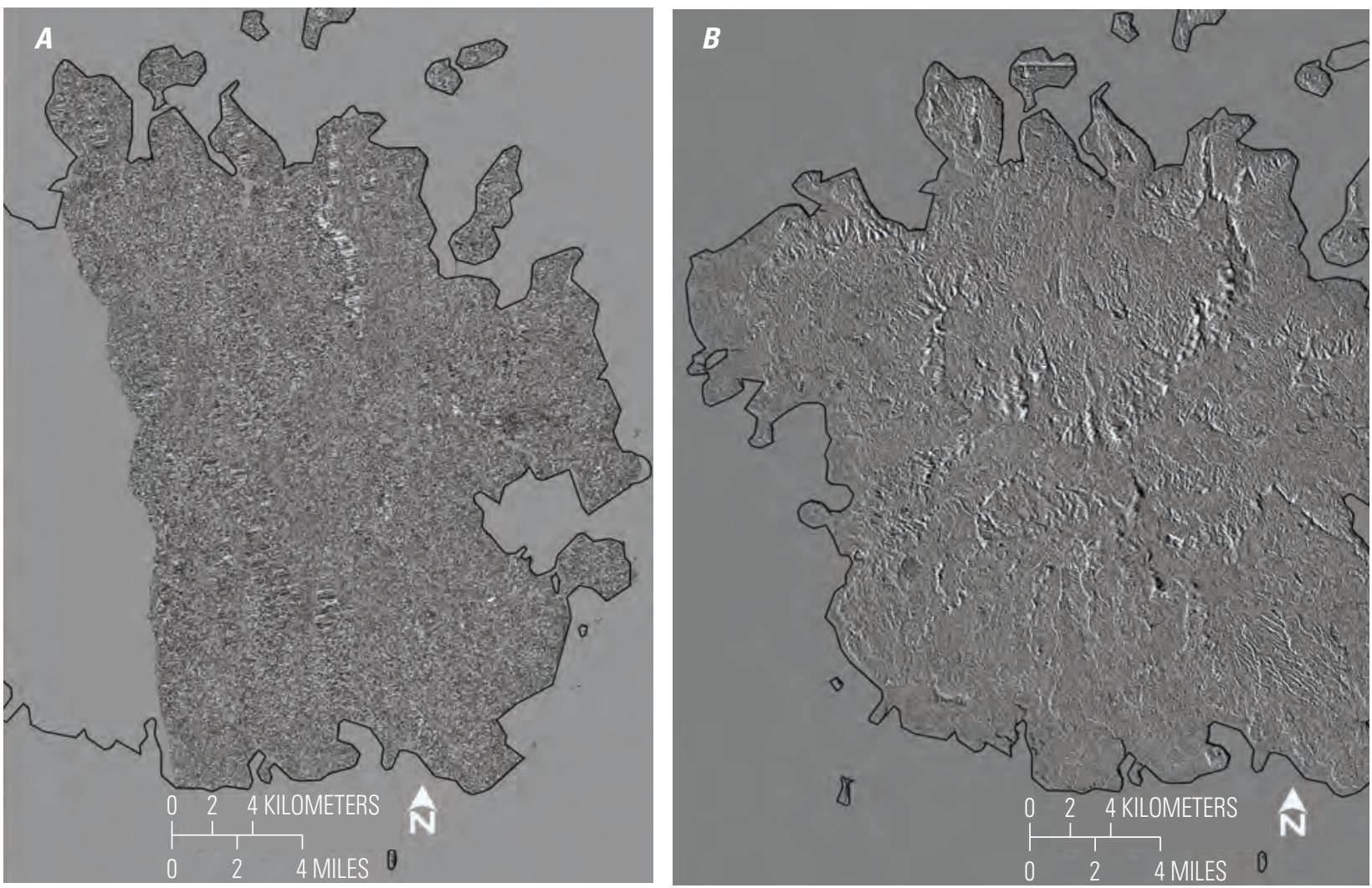

Figure 7. (A) Full-coverage 2019 East 1 January and 26 March and (B) 2020 West 15 March and 21 June change ratio products, Pohnpei, Federated States of Micronesia. No landslide features were clearly apparent on these two products.
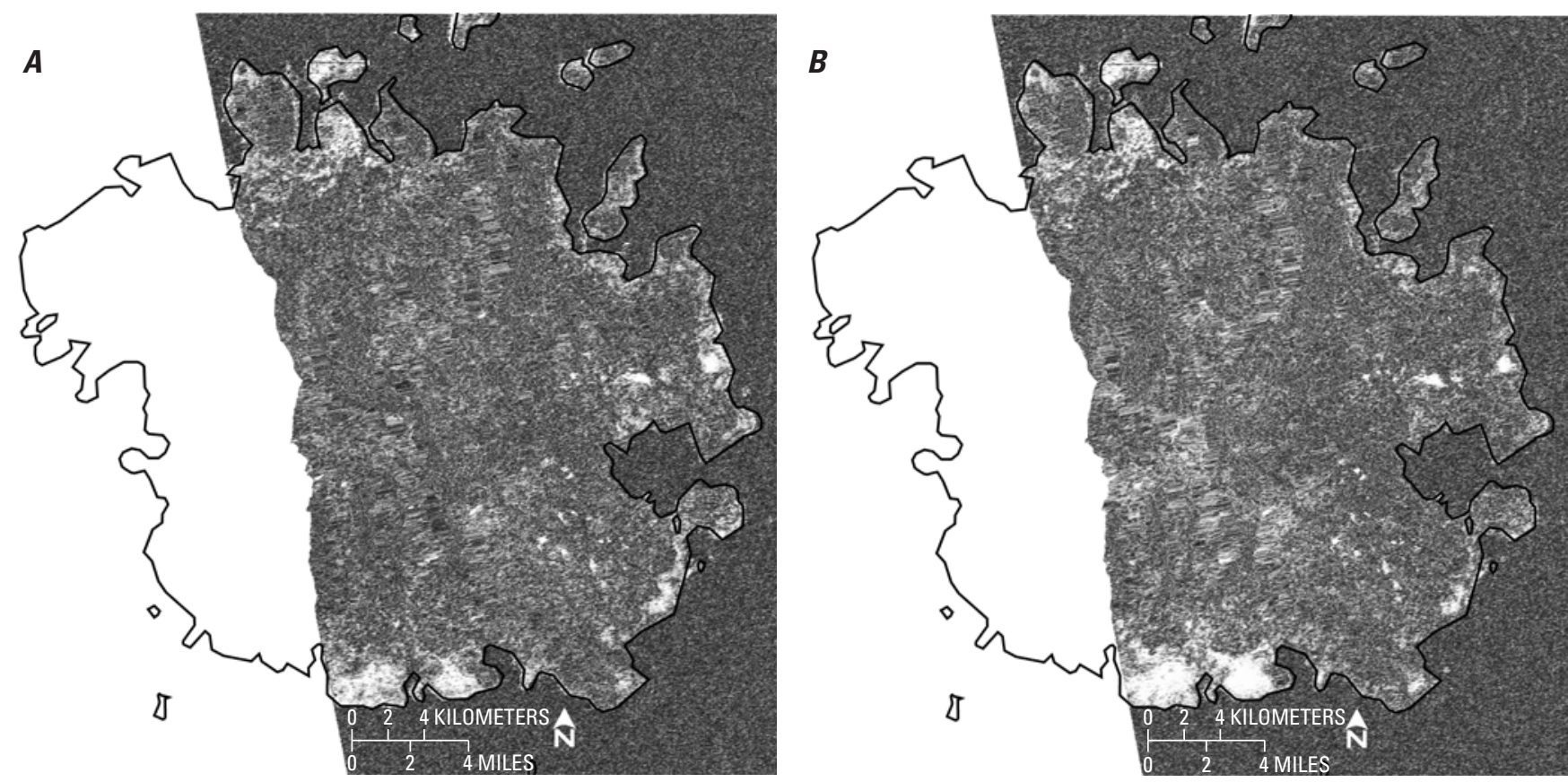

Figure 8. (A) The 2018 East 16 January and 27 March co-event and $(B) 2018$ East 27 March and 3 July post-event coherence images, Pohnpei, Federated States of Micronesia. On both maps, the gray to white transition signifies low to high values. These black and white images are recreated as color images in figures $12 \mathrm{~A}$ and $13 \mathrm{~A}$ to aid in the identification of high-coherence features. 

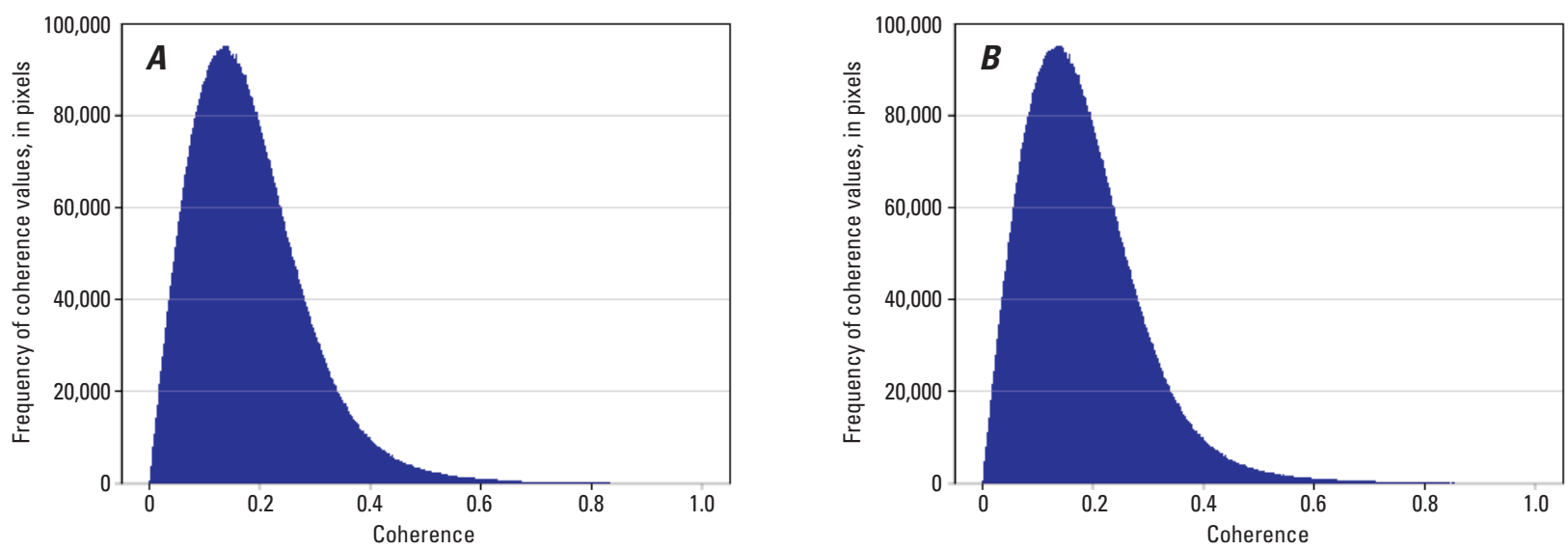

Figure 9. Histograms reflecting the $(A)$ pre-co-event 2018 East 16 January and 27 March and $(B)$ post-co-event 2018 East 27 March and 3 July coherence distributions of the coherence images shown in figure 8.

LS12, LS13, and LS16, although LS4 and LS5 exhibit minor features. As in all coherence processing, the LS7 ocean extent was cut off in the InSAR processing because processing was limited to the pre-landslide image extent.

Nine of the 11 landslide features identified on the GE images were detected in the 2018 East and West coherence change products. Of the nine, five are located on both the West and East 2018 post-event coherence sets.

\section{InSAR Interferometry}

The low coherence prevented use of phase information as an additional source in the landslide detection. Visually, the interferograms for the East and West 2018 periods displayed low coherence and lacked noticeable fringe patterns. The West 2020 interferogram did exhibit fringe patterns; however, the patterns were not sharp, reflecting low coherence and thus preventing interpretability. 


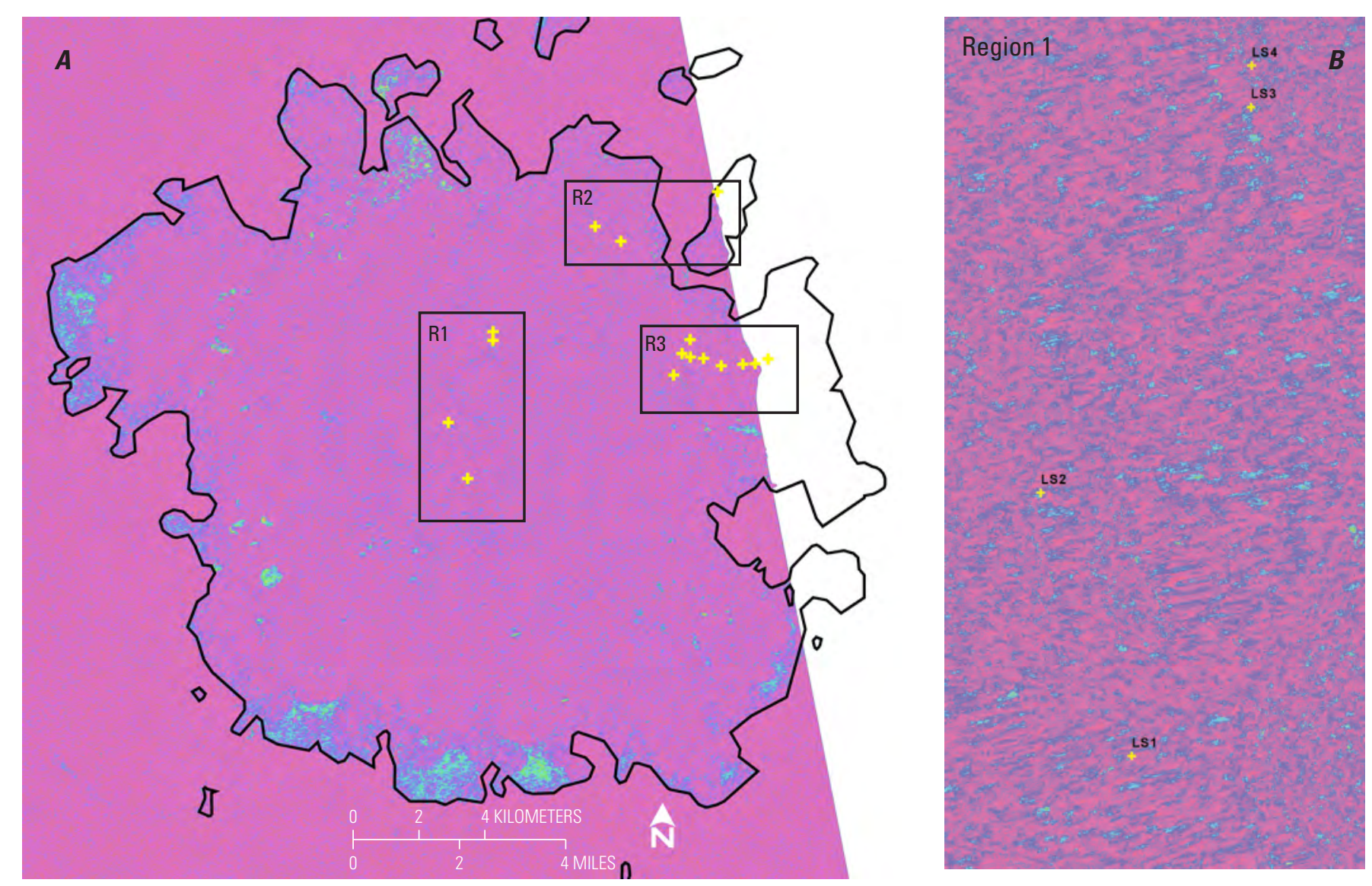

Figure 10. (A) 2018 West 7 January and 24 June coherence full scene with crosses locating the 16 HazMapper land-cover change sites and (B) Region 1 sites LS1, LS2, LS3, and LS4, (C) Region 2 sites LS5, LS6, and LS7, and (D) Region 3 sites LS8, LS9, LS10, LS11, LS12, LS13, LS14, LS15, and LS16, Pohnpei, Federated States of Micronesia. The locations for LS7 and LS16 are not contained in the West images. The highest coherences are exhibited in a green hue. 


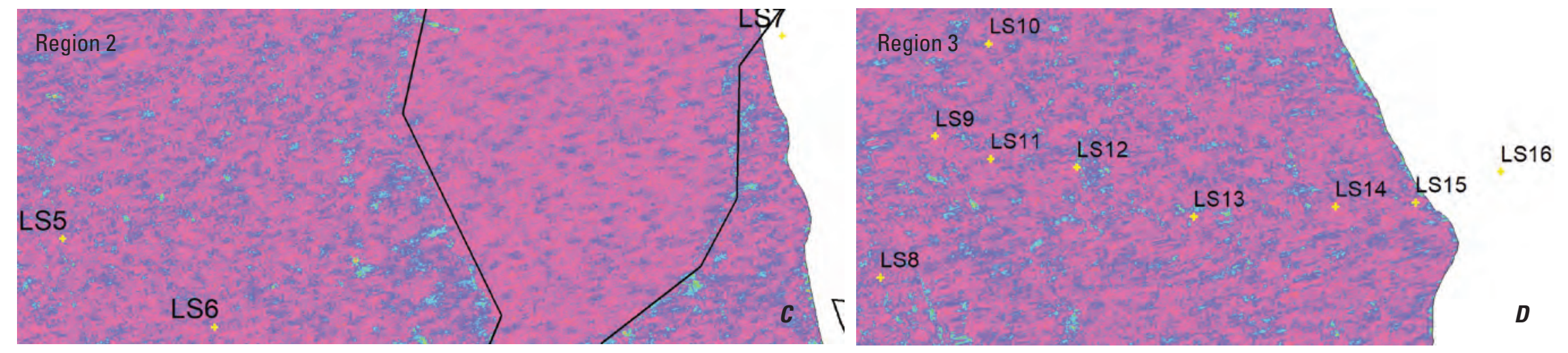

Figure 10.-Continued 


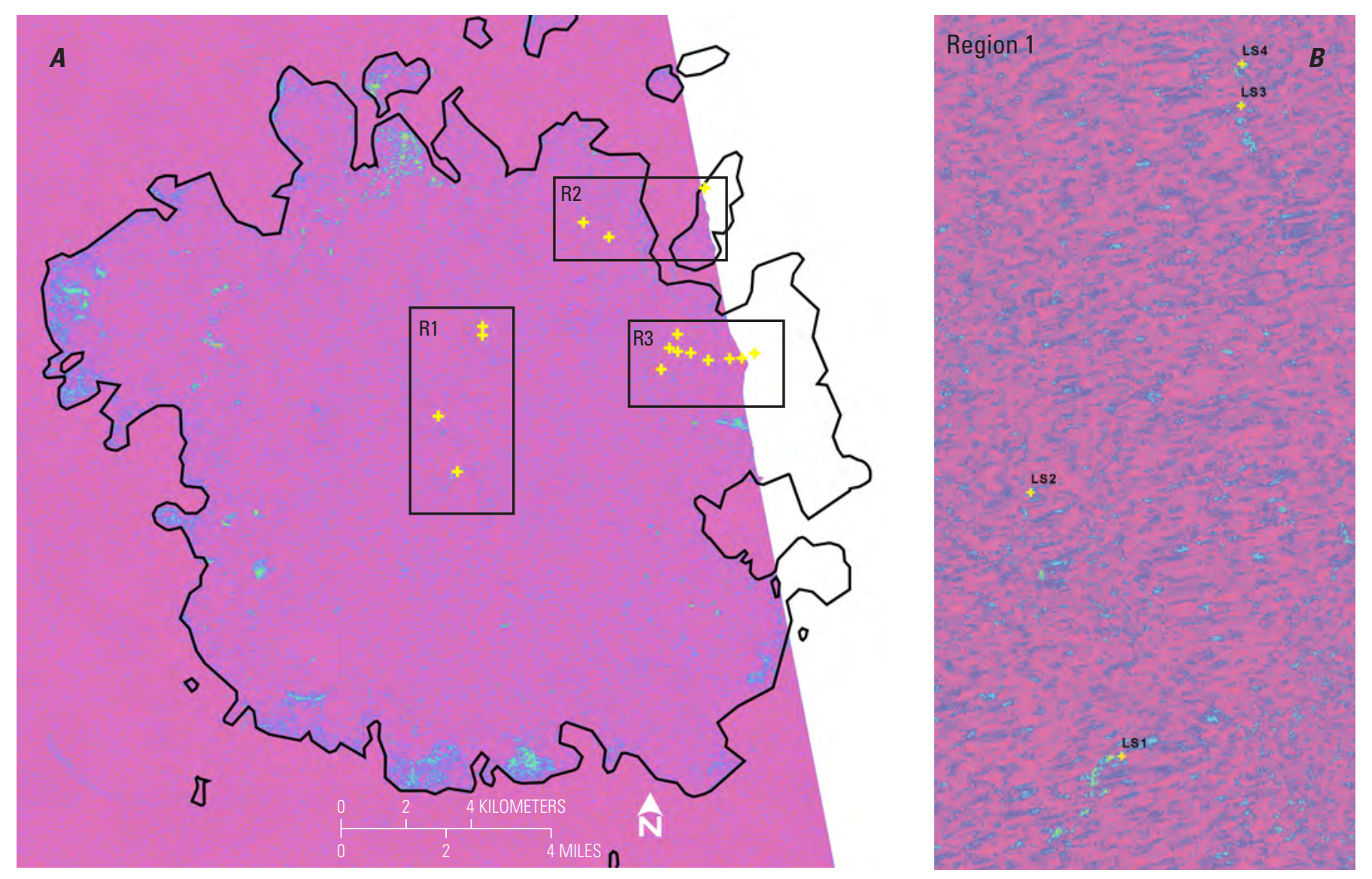

Figure 11. (A) 2018 West 24 June and 23 December coherence full scene with crosses locating the 16 HazMapper land-cover change sites and (B) Region 1 sites LS1, LS2, LS3, and LS4, (C) Region 2 sites LS5, LS6, and LS7, and (D) Region 3 sites LS8, LS9, LS10, LS11, LS12, LS13, LS14, LS15, and LS16, Pohnpei, Federated States of Micronesia. The locations for LS7 and LS16 are not contained in the West images. The highest coherences are exhibited in a green hue. 


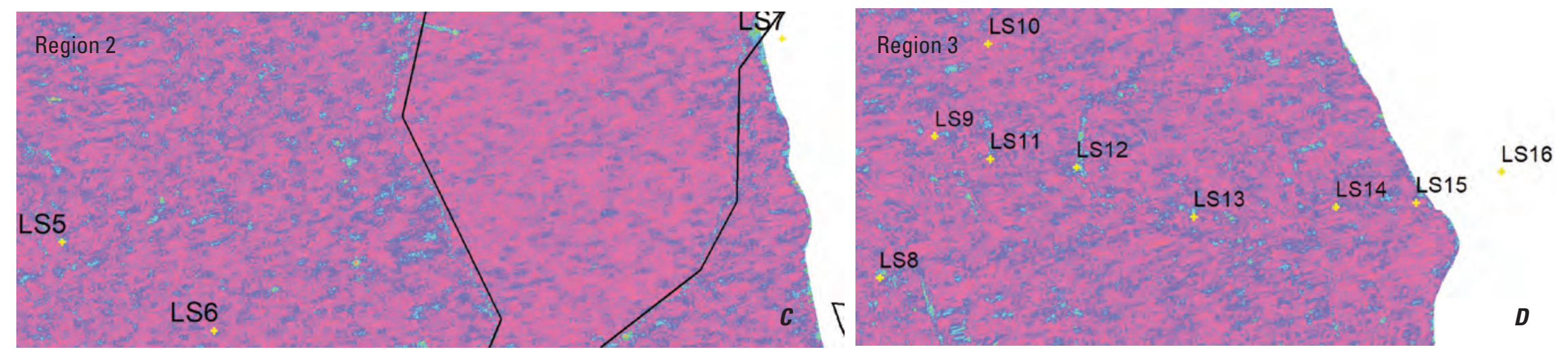

Figure 11.-Continued 

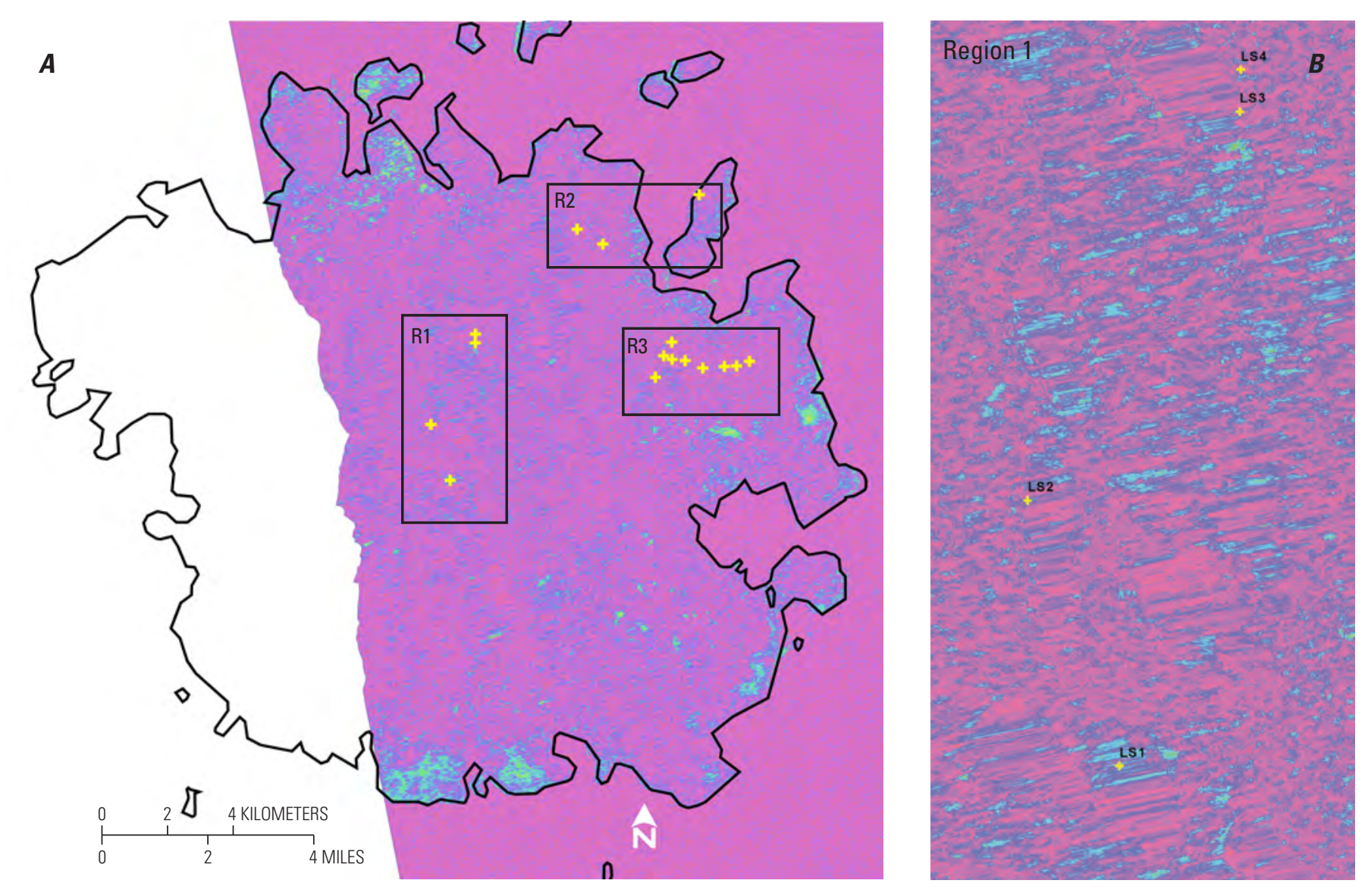

Figure 12. (A) 2018 East 16 January and 27 March coherence full scene with crosses locating the 16 HazMapper land-cover change sites and (B) Region 1 sites LS1, LS2, LS3, and LS4, (C) Region 2 sites LS5, LS6, and LS7, and (D) Region 3 sites LS8, LS9, LS10, LS11, LS12, LS13, LS14, LS15, and LS16, Pohnpei, Federated States of Micronesia. The highest coherences are exhibited in a green hue. 


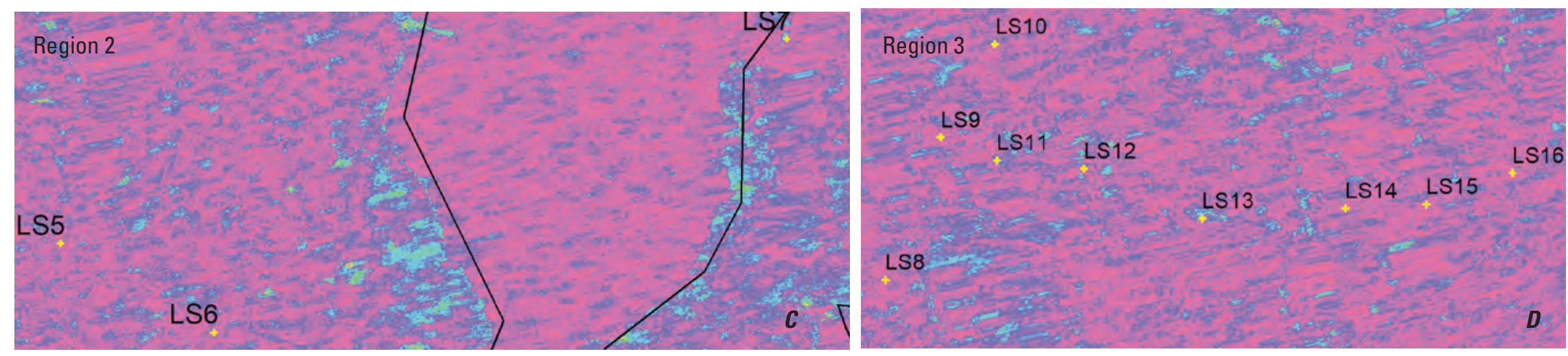

Figure 12.-Continued 

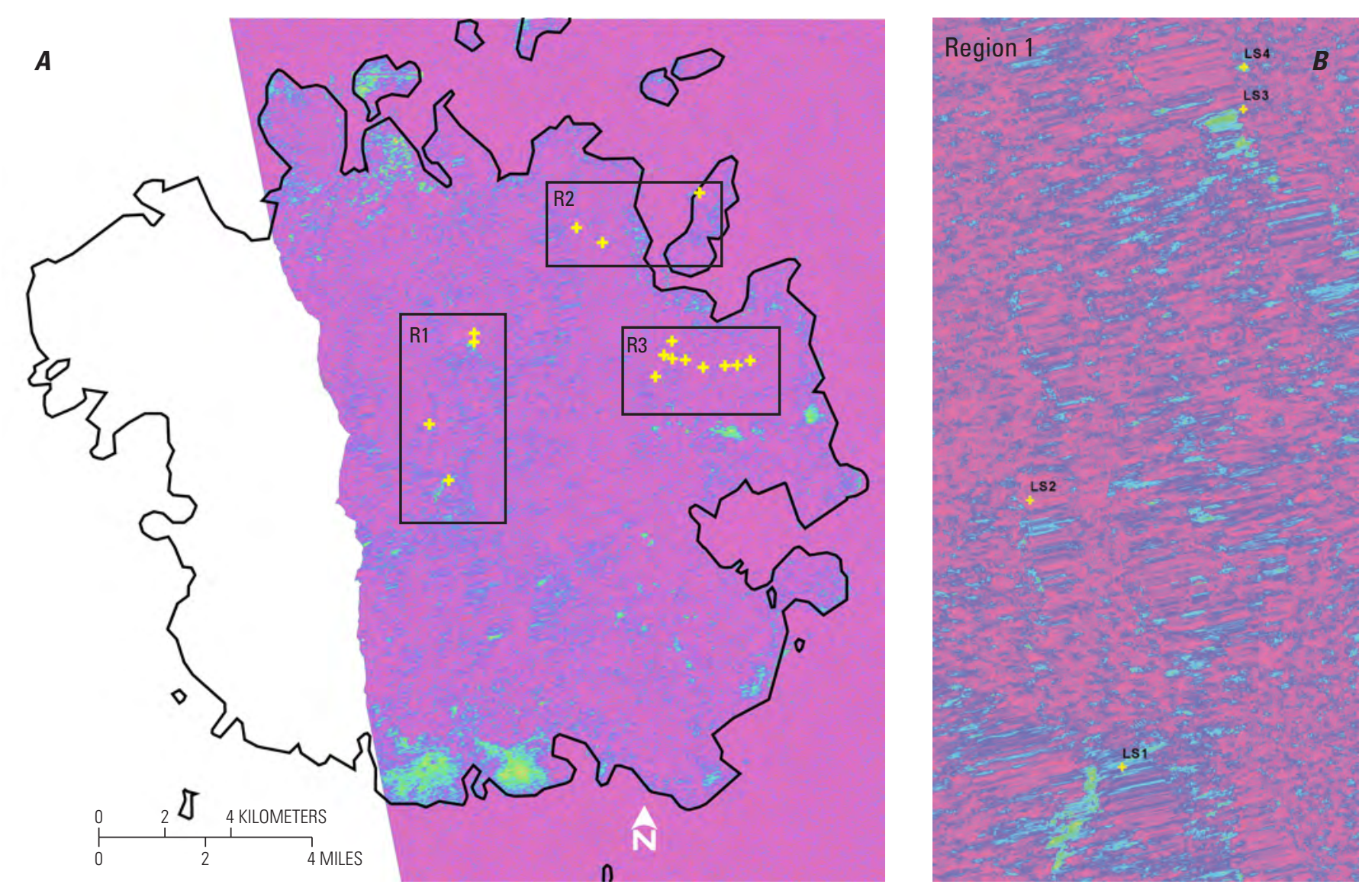

Figure 13. (A) 2018 East 27 March and 3 July coherence full scene with crosses locating the 16 HazMapper land-cover change sites and (B) Region 1 sites LS1, LS2, LS3, and LS4, (C) Region 2 sites LS5, LS6, and LS7, and (D) Region 3 sites LS8, LS9, LS10, LS11, LS12, LS13, LS14, LS15, and LS16, Pohnpei, Federated States of Micronesia. The highest coherences are exhibited in a green hue. 


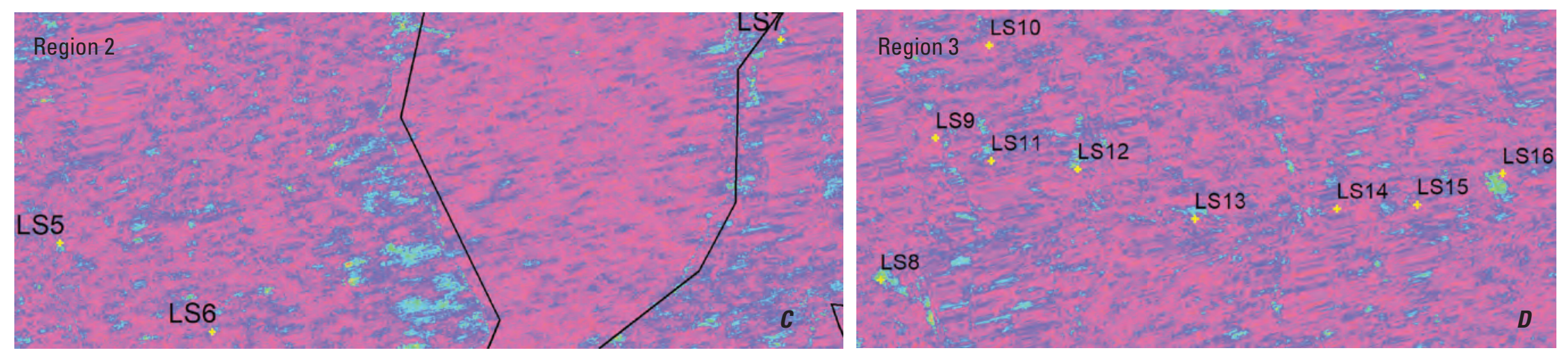

Figure 13.-Continued 


\section{Discussion}

SAR and InSAR mapping based on ALOS-2 PALSAR-2 L-band images successfully detected landslides that occurred following the March 2018 intense rainfall event on the heavily forested and mountainous island of Pohnpei in the Federated States of Micronesia. Validation was based on optical mapped land-cover change locations and visible comparison of preand post-rainfall event GE images.

One expectation of this study was that in comparison to shorter wavelength SAR systems, the interaction of L-band with the dense forest canopy could lead to decreased sensitivity of the mapping to vegetation decorrelation and result in lower backscatter variability. However, the 2018, 2019, and $2020 \mathrm{HH}$ and HV amplitude images exhibited high backscatter spatial variability that was reflected in noisy log-ratio change products. Even so, RGB composites of the 2018 East and West pre- and post-rainfall event ground-range SAR amplitude images clearly identified the two most prominent landslides, LS1 and LS7 (table 2). In addition, by using trial and error experimenting, it was found that increasing the log-ratio change detection threshold above the common 0.2 level tended to enhance the higher magnitude change contrast with the change background. Within that background, isolated high-contrast change pixels forming linear features could be identified. By applying that method, three additional landslides were identified in the West pre- and post-rainfall event images: LS5, LS8, and LS11 (table 2).

Outside of the ocean-extent LS7 landslide, the East logratio analysis only produced a barely recognizable LS1 landslide. It would seem that the shorter East pre- to post-rainfall event 71-day detection interval versus the West 169-day interval (table 1) and the lower local incidence angles of the East versus West collections (table 2) would increase the performance of the East log-ratio detection more than that of the West. Possibly, the poor performance of the East amplitude change resulted from enhanced canopy movement and leaf wetness caused by lingering storm winds and rain. Wind and rain can increase decorrelation by the forest canopy at the time of image collection, diminishing change performance.

Excluding the large LS1 and ocean-adjacent LS7 landslides, the East and West SAR amplitude landslide detection performances were moderately successful. The combined East and West detection results indicated five landslides: LS1, LS5, LS7, LS8, and LS11 (table 2). Of these five, only LS5 did not exhibit linear form on the SAR change images. Possibly the location of LS5 on a slope facing away from the SAR sensor resulting in a high local incidence angle brought about the truncated detection of the landslide linear form. The additional log-ratio processing applied to the four East images spanning 2019 and the West pair of 2020 did not detect landslide occurrences.

Coherence image pairs created as part of the InSAR processing also indicated L-band decorrelation by the dense forest and other physical and geometric factors. All 2018 East and West co-event and post-event pairs exhibited low coherence throughout the entire island interior forest landscape, preventing interpretable use of the produced interferograms. A similar correspondence was found with the interferogram spanning 2020. Comparable findings have been reported by others using L-band image data in heavily forested areas (Ge and others, 2019; Burrows and others, 2020; Ohki and others, 2020). Independent of that result, 2018 East and West co-event and post-event coherence products were examined as an indicator of landslide occurrence.

Our co-event coherence change method differs from the common strategy in InSAR coherence landslide detection. Normally, the co-event pair closely brackets the landslide event (for example, Tzouvaras and others, 2020). While our co-event pair does bracket the rainfall event, in the East, the pre-image collection was about 2 months before the rainfall event. In the West, the co-event collections occurred more than 2 months before and more than 3 months after the rainfall event. Additionally, the same central image was used in both the co-event and post-event calculations, and no pre-event and post-event averages could be calculated to moderate variability. Although these limitations may have reduced the potential detection discrimination, the combined results indicate a high robustness of the coherence method based on L-band data to identify change.

Co-event and post-event coherence change processing overcame the acute temporal and spatial decorrelation and the very limited image dataset to generate products that exhibited clearly identifiable landscape changes related to landslide occurrences. The InSAR coherence change detection identified five landslides in the West orbital track and nine landslides in the East track (table 2). The higher performance in the East track compared to the West may reflect the longer times between image collections and steeper local incidence angles in the West compared to the East collections. Although the detection was based on the visual comparison of the two pairs, the isolation and contrast of the change was clear and adaptable to operational methods.

Outside of the pre-event land extent excluding the detection of LS7 into the coastal ocean, only LS15 was not detected in either the log-ratio or coherence change analyses. LS15 exhibited as a landslide feature in the $2020 \mathrm{GE}$ image and as forested in the $2013 \mathrm{GE}$ image. Although associated with a moderate local incidence angle, LS15 was the smallest of all landslide features at about $70 \mathrm{~m}$ long and $15 \mathrm{~m}$ wide (table 2). Whether the small size, a combination of size and terrain, or other factors resulted in the nondetection is not with discernable with this data. However, with respect to the objective to assess the detectability of landslides in the densely forested and mountainous island of Pohnpei in the Federated States of Micronesia, the study successfully demonstrated that straightforward application of SAR and InSAR processing tools detected 10 of 11 landslides visible in GE imagery.

Further refinements to the methodology could include translation of the successful visual detections to more automated approaches. That translation may involve operational implementation of the log-ratio and coherence processing and 
implementation of methods, such as those based on autocorrelation of log-ratio images (Mondini, 2017) and histogram matching and differencing of coherence images (Burrows and others, 2020) to identify land-cover change. From identified changes, procedures could be developed for more automated detection to detect landslides. Those results could then provide a structure for design and implementation of strategic monitoring using the higher frequency SAR image collections.

\section{Conclusion}

This study was undertaken to assess the detectability of landslides in the cloud-prone and densely forested and mountainous island of Pohnpei in the Federated States of Micronesia. To further investigate the widely documented landslide co-occurrence with intense rainfall, a limited number of available ALOS-2 PALSAR-2 L-band images collected on two adjacent orbit paths bracketing a 2018 intense rainfall event, and additional images collected in 2019 and 2020, were processed. The study took advantage of field reconnaissance following the intense rainfall event and land changes located with optical image analyses and Google Earth (GE) images.

The landslide detection included ground-range synthetic aperture radar (SAR) and interferometric SAR (InSAR) processing. Both detection methods were used to process the more eastern and more western image sets separately as well as to process images from each year separately; this study focused on images collected before and after an intense rainfall event that occurred mid-March 2018.

The 2018 SAR processing of co-event pairs identified 5 of the 11 landslides visible on the 2020 GE image. No landcover change features associated with landslides were detected in the 2019 or 2020 log-ratio image processing.

The InSAR processing of the co-event and post-event image pairs produced both coherence and phase-change products. The low levels of the generated coherence products eliminated the use of phase-change products for landslide detection. Visual comparison of the 2018 co-event and postevent coherence products indicated that 5 of 11 landslides visible on the $2020 \mathrm{GE}$ image were identified on the orbital track spanning the west side of the island, and 9 were identified on the orbital track spanning the east side of the island. Excluding the landslide extending into the ocean outside coherence limited to the pre-event image extent, only one landslide was not observable in the coherence results. As in the log-ratio detection, only land-cover change features identified as landslides in comparison with GE images were observed in the coherence comparisons.

Phase change was not applicable because of low coherence throughout the island interior, and the ground-range SAR log-ratio method identified half of the landslides observable on the $2020 \mathrm{GE}$ image. Co-event and post-event coherence comparisons were more successful, detecting all but 1 of the 10 landslides within the pre-event image extent limit of the
InSAR processing. Combined, the SAR log-ratio and InSAR coherence change detections identified all but one of the landslides visible in the GE images and included substantial redundancy in overlap of the methods. The SAR and InSAR methods used are straightforward and can support land-cover change monitoring as demonstrated in this study.

Despite Pohnpei's rugged mountainous terrain and the high temporal and spatial decorrelations inherent in this change processing, landslides were successfully detected. That robustness indicates that an increased collection frequency of ALOS-2 PALSAR L-band images would support systematic monitoring of land-cover change on the scale reported in this study and increase the timeliness of the monitoring. Systematic monitoring can help improve government awareness and inform coordinated government response, particularly in the less populated interior island areas.

\section{References Cited}

Aimaiti, Y., Liu, W., Yamazaki, F., and Maruyama, Y., 2019, Earthquake-induced landslide mapping for the 2018 Hokkaido Eastern Iburi earthquake using PALSAR-2 data: Remote Sensing (Basel), v. 11, no. 20, article 2351, accessed August 4, 2021, at https://doi.org/10.3390/ rs11202351.

Burrows, K., Walters, R.J., Milledge, D., and Densmore, A.L., 2020, A systematic exploration of satellite radar coherence methods for rapid landslide detection: Natural Hazards and Earth System Sciences, v. 20, no. 11, p. 3197-3214, accessed August 4, 2021, at https://doi.org/10.5194/nhess20-3197-2020.

Casagli, N., Cigna, F., Bianchini, S., Hölbling, D., Füreder, P., Righini, G., Del Conte, S., Friedl, B., Schneiderbauer, S., Iasio, C., Vlcko, J., Greif, V., Proske, H., Granica, K., Falco, S., Lozzi, S., Mora, O., Arnaud, A., Novali, F., and Bianchi, M., 2016, Landslide mapping and monitoring by using radar and optical remote sensing-Examples from the EC-FP7 project SAFER: Remote Sensing Applications: Society and Environment, v. 4, p. 92-108, accessed August 6, 2021, at https://www.sciencedirect.com/science/article/pii/ S2352938516300635.

Del Ventisette, C., Righini, G., Moretti, S., and Casagli, N., 2014, Multitemporal landslides inventory map updating using spaceborne SAR analysis: International Journal of Applied Earth Observation and Geoinformation, v. 30, p. 238-246. [Also available at https://doi.org/10.1016/ j.jag.2014.02.008.]

Federated States of Micronesia, 2017, Pohnpei Joint State Action Plan for Disaster Risk Management and Climate Change, accessed June 30, 2021, at https://bsrp.gsd.spc.int/ wp-content/uploads/2017/08/JSAP-report_web-1.pdf. 
Federated States of Micronesia, 2019a, Climate Change Profile, Version 1, accessed August 5, 2021, at http://ccp rojects.gsd.spc.int/wp-content/uploads/2019/12/FSMClimate-Change-Profile.pdf.

Federated States of Micronesia, 2019b, Disaster Management Reference Handbook, accessed June 30, 2021, at https://reli efweb.int/sites/reliefweb.int/files/resources/disaster-mgmtref-hdbk-FSM.pdf.

Ge, P., Gokon, H., Meguro, K., and Koshimura, S., 2019, Study on the intensity and coherence information of highresolution ALOS-2 SAR images for rapid massive landslide mapping at a pixel level: Remote Sensing (Basel), v. 11, no. 23, article 2808, accessed August 4, 2021, at https://doi.org/10.3390/rs11232808.

Harp, E.L., Reid, M.E., and Michael, J.A., 2004, Hazard analysis of landslides triggered by Typhoon Chata'an on July 2, 2002, in Chuuk State, Federated States of Micronesia (ver. 1.1, July 2021): U.S. Geological Survey Open-File Report 2004-1348, 22 p., 2 pls., scale 1:25,000, accessed August 4, 2021, at https://doi.org/10.3133/ofr20041348.

Le Toan, T., Quegan, S., Woodward, I., Lomas, M., Delbart, N., and Picard, G., 2004, Relating radar remote sensing of biomass to modelling of forest carbon budgets: Climatic Change, v. 67, p. 379-402. [Also available at https://doi.org/ 10.1007/s10584-004-3155-5.]

Mondini, A.C., 2017, Measures of spatial autocorrelation changes in multitemporal SAR images for event landslides detection: Remote Sensing (Basel), v. 9, no. 6, article 554. [Also available at https://doi.org/10.3390/rs9060554.]

Natsuaki, R., 2018, L-band SAR disaster monitoring for harbor facilities using interferometric analysis, in Marghany, M., ed., Advanced remote sensing technology for synthetic aperture radar applications, tsunami disasters, and infrastructure: London, IntechOpen, accessed August 4, 2021, at https://doi.org/10.5772/intechopen.81465.

Ohki, M., Abe, T., Tadono, T., and Shimada, M., 2020, Landslide detection in mountainous forest areas using polarimetry and interferometric coherence: Earth, Planets and Space, v. 72, article 67, 14 p., accessed August 4, 2021, at https://doi.org/10.1186/s40623-020-01191-5.

Panuju, D.R., Paull, D.J., and Trisasongko, B.H., 2019, Combining binary and post-classification change analysis of augmented ALOS backscatter for identifying subtle land cover changes: Remote Sensing (Basel), v. 11, no. 1, article 100, 24 p. [Also available at https://doi.org/10.3390/ rs11010100.]

Ramsey, E., III, 1998, Radar remote sensing of wetlands, in Lunetta, R., and Elvidge, C., eds., Remote sensing change detection-Environmental monitoring methods and applications: Michigan, Ann Arbor Press, Inc., p. 211-243.
Ramsey, E., III, Lu, Z., Rangoonwala, A., and Rykhus, R., 2006, Multiple baseline radar interferometry applied to coastal land cover classification and change analyses: GIScience \& Remote Sensing, v. 43, no. 4, p. 283-309, accessed August 4, 2021, at https://doi.org/10.2747/15481603.43.4.283.

Ramsey, E., III, Rangoonwala, A., and Jones, C.E., 2015, Structural classification of marshes with polarimetric SAR highlighting the temporal mapping of marshes exposed to oil: Remote Sensing (Basel), v. 7, no. 9, p. 11295-11321, accessed August 4, 2021, at https://doi.org/10.3390/ rs70911295.

Raspini, F., Bardi, F., Bianchini, S., Ciampalini, A., Del Ventisette, C., Farina, P., Ferrigno, F., Solari, L., and Casagli, N., 2017, The contribution of satellite SAR-derived displacement measurement in landslide risk management practices: Natural Hazards, v. 86, p. 327-351. [Also available at https://doi.org/10.1007/s11069-016-2691-4.]

Raucoules, D., de Michele, M., and Aunay, B., 2020, Landslide displacement mapping based on ALOS-2/ PALSAR-2 data using image correlation techniques and SAR interferometry-Application to the Hell-Bourg landslide (Salazie Circle, La Réunion Island): Geocarto International, v. 35, no. 2, p. 113-127, accessed August 4, 2021, at https://doi.org/10.1080/10106049.2018.1508311.

Ryan, W.B.F., Carbotte, S.M., Coplan, J.O., O’Hara, S., Melkonian, A., Arko, R., Weissel, R.A., Ferrini, V., Goodwillie, A., Nitsche, F., Bonczkowski, R., and Zemsky, R., 2009, Global Multi-Resolution Topography synthesis: Geochemistry, Geophysics, Geosystems, v. 10, no. 3, 9 p., accessed August 10, 2021, at https://doi.org/10.1029/ 2008 GC002332.

Scheip, C.M., and Wegmann, K.W., 2021, HazMapper-A global open-source natural hazard mapping application in Google Earth Engine: Natural Hazards and Earth System Sciences, v. 21, no. 5, p. 1495-1511, accessed August 4, 2021, at https://doi.org/10.5194/nhess-21-1495-2021.

Thirion, L., Colin, E., and Dahon, C., 2006, Capabilities of a forest coherent scattering model applied to radiometry, interferometry, and polarimetry a P- and L-band: IEEE Transactions on Geoscience and Remote Sensing, v. 44, no. 4, p. 849-862. [Also available at https://doi.org/10.1109/ TGRS.2005.862523.]

Tzouvaras, M., Danezis, C., and Hadjimitsis, D.G., 2020, Small scale landslide detection using Sentinel-1 interferometric SAR coherence: Remote Sensing, v. 12, 33 p. [Also available at https://dx.doi.org/10.3390/rs12101560.] 
Xue, D., Yu, X., Jia, S., Chen, F., and Li, X., 2018, Study on landslide disaster extraction method based on spaceborne SAR remote sensing images-Take ALOS PALSAR for an example: The International Archives of the Photogrammetry, Remote Sensing and Spatial Information Sciences, v. XLII-3, p. 2023-2027. [Also available at https://doi.org/10.5194/isprs-archives-XLII-3-2023-2018.]
Yun, S.-H., Hudnut, K., Owen, S., Webb, F., Simons, M., Sacco, P., Gurrola, E., Manipon, G., Liang, C., Fielding, E., Milillo, P., Hua, H., and Coletta, A., 2015, Rapid damage mapping for the $2015 M_{w} 7.8$ Gorkha earthquake using synthetic aperture radar data from COSMO-SkyMed and ALOS-2 satellites: Seismological Research Letters, v. 86, no. 6, p. 1549-1556. [Also available at https://doi.org/ $10.1785 / 0220150152$.

For more information about this publication, contact

Director, Wetland and Aquatic Research Center

U.S. Geological Survey

700 Cajundome Blvd.

Lafayette, LA 70506-3152

For additional information, visit

https://www.usgs.gov/centers/wetland-and-

aquatic-research-center-warc

Publishing support provided by

Lafayette Publishing Service Center 



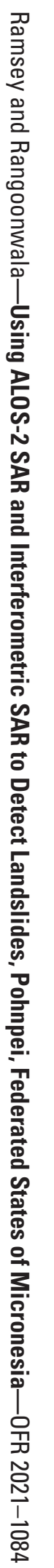

